\title{
Simulating changes in the terrestrial biosphere during the last glacial/interglacial transition
}

\author{
Peter Köhler and Hubertus Fischer \\ Alfred Wegener Institute for Polar and Marine Research, P.O. Box 1201 61, \\ D-27515 Bremerhaven, Germany. \\ Phone: +49.471.4831.1687. Fax: +49.471.4831.1149. \\ (pkoehler@awi-bremerhaven.de,hufischer@awi-bremerhaven.de)
}

\begin{abstract}
The state of the terrestrial biosphere during the Holocene and the Last Glacial Maximum (LGM) was estimated from data bases and steady state simulations in former studies. Here, we use these previous estimates and run a simple globally averaged box model of the terrestrial carbon stocks driven by various paleorecords (temperature, $p \mathrm{CO}_{2}$, sea level) from the LGM across termination I to the Holocene to determine which forcing might be appropriate to explain observed changes in the biosphere. Former forcing strength of this type of model on recent climate changes is not transferable to our problem of glacial/interglacial variations. The modelled terrestrial carbon stock at the LGM is about $1600 \mathrm{PgC}, 600 \mathrm{PgC}$ less than in preindustrial times. The oceanic release of carbon during the last $20 \mathrm{kyr}$ seems to be in phase with the atmospheric $p \mathrm{CO}_{2}$ record, but four times larger than the $p \mathrm{CO}_{2}$ increase due to the build-up of the terrestrial stocks. Calculated changes in oceanic $\delta^{13} \mathrm{C}$ correspond well with data and suggest not only a significant role of the biosphere on atmospheric $\delta^{13} \mathrm{C}$ during stable climate conditions such as the LGM or the Holocene, but also during the transition. A final identification of the relative importance of either climate change or $\mathrm{CO}_{2}$ fertilization for fixation of carbon in the terrestrial biosphere is not yet possible.
\end{abstract}

Keywords: terrestrial biosphere, glacial/interglacial transition, Last Glacial Maximum, carbon isotope discrimination, $\mathrm{CO}_{2}$ fertilization, $\mathrm{Q}_{10}$ factor

\section{Introduction}

Variations of the earth climate determined also changes in carbon stocks and isotopic signatures of the terrestrial biosphere. Experimental constraints on the impacts of those forcings (e.g. temperature, atmospheric carbon dioxide partial 
pressure) on different ecosystems, vegetation, and soil differ widely and are a matter of current debate (see overview in Walker and Steffen, 1996; Walker et al., 1999). The changes in terrestrial carbon stocks from the LGM to the present were the subject of several modelling and data-based studies over the last decade (Table 1). While first estimates of LGM carbon stocks have been proven to be very unlikely (Adams et al., 1990; Prentice and Fung, 1990; Bird et al., 1994; Friedlingstein et al., 1995b), the most realistic range of the change in terrestrial carbon stock of the more recent studies varies between 270-1106 $\mathrm{PgC}$ (Table 1). This range was narrowed to $300-700 \mathrm{PgC}$ by a mass-balance approach considering known changes in atmospheric, oceanic and terrestrial carbon stocks and $\delta^{13} \mathrm{C}$ (Bird et al., 1994).

Even though the total carbon stored in terrestrial ecosystems is much smaller than the 38,000 $\mathrm{PgC}$ found in dissolved inorganic carbon (DIC) in the oceans the role of the terrestrial biosphere during glacial/interglacial changes deserves further investigation. From the isotopic record of atmospheric $\mathrm{CO}_{2}$ trapped in Antarctic ice cores it was deduced that the global carbon cycle has operated in two distinct primary modes, one for relatively stable climatic conditions such as the Holocene and the LGM and the other for the transitions between stable climate states (Smith et al., 1999). While the glacial/interglacial changes in atmospheric $\mathrm{CO}_{2}$ and $\delta^{13} \mathrm{C}$ were mainly controlled by processes in the ocean, the isotopic signature of $\mathrm{CO}_{2}$ during the Holocene and the LGM point to dominant variations in the terrestrial biosphere carbon stocks (Indermühle et al., 1999; Fischer et al., 2003). However, the terrestrial influence on variations in the atmospheric $\mathrm{CO}_{2}$ records over the Holocene is still a matter of debate (Broecker et al., 2001; Brovkin et al., 2002a). Because the marine biological productivity was proposed to be another possible driver for the observed dynamics in the atmospheric $\delta^{13} \mathrm{CO}_{2}$ record (Brovkin et al., 2002b) it becomes clear that the uncertainties in data and model results are still too large to come to definite conclusions.

The attempts to model the terrestrial biosphere started with simple box models (e.g. Emanuel et al., 1984), which are still in use nowadays (Prentice et al., 2001; Randerson et al., 2002). In recent times several complex process-based terrestrial carbon models (TCM) - of which some were dynamic global vegetation models (DGVMs) — were developed and applied for mostly anthropogenic climate change analysis (Heimann et al., 1998; Kicklighter et al., 1999; Cramer et al., 2001; McGuire et al., 2001; Dargaville et al., 2002) and seldomly on the paleoclimatic record (Kaplan et al., 2002; Gerber et al., 2003). Somewhat simpler versions of the DGVMs are already implemented in earth models of intermediate complexity (EMICs) (Claussen et al., 2002).

Here, we try to add to current discussions by a transient modelling approach driven by paleoclimatic records. We especially use informations on past atmospheric carbon dioxide which is one of the few paleorecords directly measur- 
able. Our transient approach already implies the use of a simple model, otherwise missing data constraints would dominate model dynamics. So far, such terrestrial box models were used to analyse the effects of land-use, temperature change or anthropogenic $p \mathrm{CO}_{2}$ increase on the terrestrial carbon storage capacity (e.g. Joos and Bruno, 1998; Kheshgi et al., 1996; Prentice et al., 2001), but were never applied on glacial/interglacial timescales. We rely on this simple approach since we feel that a transient model approach might be needed in view of the long residence time of carbon in soils to come to unbiased results. Transient simulations over several millennia were until now impossible for global circulation models (GCMs) coupled to TCMs for reasons of computing capacity and even transient runs with EMICs were seldomly performed (e.g. Brovkin et al., 2002a). Some ocean box models of the PANDORA/CYCLOPS type were applied for glacial-interglacial transient simulations (e.g. Sigman et al., 1998; Jones et al., 2002). Especially for the latter type of models the terrestrial biosphere was so far ignored. Our approach fills this gap and this study presents the terrestrial part of a coupled global carbon cycle box model to be used in future studies.

In the following we will present and discuss in detail the developed box model of the terrestrial biosphere. We will expand on a model (Emanuel et al., 1984; Kheshgi et al., 1996) to be applied for glacial times and test it for preindustrial conditions (PRE) first. Then the model will be applied for the LGM (25-20 kyr BP), Termination I (20-10 kyr BP) and the Holocene (10-0 kyr BP) forced by paleoclimatic data. We further investigate which driving forces (temperature, $p \mathrm{CO}_{2}$, ratio of $\mathrm{C}_{3}$ and $\mathrm{C}_{4}$ plants, grassland/forest succession, sea level change) might trigger the dynamics of the model on glacial/interglacial timescales and which are the limitations of our approach.

\section{The Terrestrial Biosphere Model}

The box model of the terrestrial biosphere we use in this study is based on the work of Emanuel et al. (1984). This model consists of a globally averaged biosphere and was used widely within the last decades to estimate past, present and future changes in the terrestrial biosphere (Siegenthaler and Oeschger, 1987; Harvey, 1989; Kheshgi et al., 1996; Prentice et al., 2001). A slightly different version of the model was used until recently as the terrestrial part of the "Bern CC model" (Siegenthaler and Oeschger, 1987; Joos et al., 1996; Bruno and Joos, 1997; Joos and Bruno, 1998; Marchal et al., 1998; Indermühle et al., 1999; Joos et al., 1999a,b; Kicklighter et al., 1999; Marchal et al., 1999) mostly in deconvolution studies without the use of any climate driven biospheric changes.

In the predecessor of our model carbon and $\delta^{13} \mathrm{C}$ of ground, tree vegetation and 
soil is simulated for five different compartments. We expand the model by (a) splitting ground vegetation into two boxes using the $\mathrm{C}_{4}$ or $\mathrm{C}_{3}$ photosynthetic pathway and (b) dividing the soil pool in two boxes with different turnover times. $\mathrm{C}_{4}$ plants were ignored in the former studies of this model type but they will be important for the glacial/interglacial dynamics of the $\delta^{13} \mathrm{C}$ signatures.

Thus, our model consists of seven different well-mixed compartments: ground vegetation using the $\mathrm{C}_{4}(\mathrm{C} 4)$ and $\mathrm{C}_{3}(\mathrm{C} 3)$ photosynthetic pathway, non-woody (NW) and woody (W) parts of trees, detritus or above-ground litter (D), fast decomposing soil or below-ground litter (FS) and slow decomposing soil (SS) (Figure 1). All trees follow the $\mathrm{C}_{3}$ photosynthetic pathway. Atmospheric $p \mathrm{CO}_{2}$ concentrations are prescribed from ice core data (see next section). For each compartment and for each time step the changes in the carbon content and of $\delta^{13} \mathrm{C}$ were calculated.

Net primary production (NPP or here $P_{i}$ ) increases the standing biomass $C_{i}$ in the compartments $i$ covering the ground vegetation (C4, C3) and non-woody parts of trees (NW) following a logistic function (for $\nu_{i}$ and $\rho_{i}$ see below):

$$
P_{i}=\nu_{i} \cdot C_{i}-\rho_{i} \cdot C_{i}^{2}
$$

Through Eq. 2.1 biomass growth will be restricted when the standing carbon of the photosynthetic compartments approach their steady state values $C_{i}^{*}$. This is a very simple, but effective mechanism used widely in dynamical systems which prevents the model from reaching forbidden states. As we operate here with a globally average model this approach (which does not include any physiological processes of photosynthetic production) seems justified.

Together with the fluxes $F_{i j}=\alpha_{i j} \cdot C_{i}$ from box $i$ to box $j$ the changes in the biomass over time $t$ in each photosynthetic (Eq. 2.2) and non-productive compartment (Eq. 2.3) are given as:

$$
\begin{aligned}
& \frac{\mathrm{d} C_{i}}{\mathrm{~d} t}=\left(\nu_{i}-\sum_{j} \alpha_{i j}\right) \cdot C_{i}-\rho_{i} \cdot C_{i}^{2}, i \in[\mathrm{NW}, \mathrm{C} 3, \mathrm{C} 4] \\
& \frac{\mathrm{d} C_{i}}{\mathrm{~d} t}=\sum_{j} \alpha_{j i} \cdot C_{j}-\sum_{j} \alpha_{i j} \cdot C_{i}, i \in[\mathrm{D}, \mathrm{FS}, \mathrm{SS}] .
\end{aligned}
$$

The ingoing flux to the woody compartment of trees is assumed to be proportional to the NPP of the non-woody parts of trees $\left(\mathrm{d} C_{\mathrm{W}} / \mathrm{d} t=r_{\mathrm{NPP}} \cdot P_{\mathrm{NW}}-\right.$ $\left.\sum_{j} \alpha_{i j} \cdot C_{i}\right)$.

The sum of the rate coefficients is defined by the inverse of the box specific turnover times $\tau_{i} \cdot t_{i}^{\mathrm{R}}=\left(\nu_{i}-\sum_{j} \alpha_{i j}\right)^{-1}$ serve as time constants or recovery times for the exponential growth of the biomass. The steady state solutions 
$C_{i}^{*}$ of Eq. 2.2 lead to the definition of the saturation constants $\rho_{i}=\left(C_{i}^{*} \cdot t_{i}^{\mathrm{R}}\right)^{-1}$.

Outgoing fluxes $F_{i j}$ of the vegetation compartments are split into inputs to detritus or above-ground litter $\left(\left(1-\theta_{i}\right) \cdot F_{i j}\right)$ and to fast decomposing soil or below-ground litter $\left(\theta_{i} \cdot F_{i j}\right)$ as defined by their soil-forming fraction $\theta_{i}$. Similarly, the outgoing fluxes of detritus and the soil boxes are split into a respiratory flux $\left(\vartheta_{i} \cdot F_{i j}\right)$ to the atmosphere and one covering transfer fluxes to soil compartments with longer turnover times $\left(\left(1-\vartheta_{i}\right) \cdot F_{i j}\right)$.

We assume that during photosynthesis an isotopic fractionation of the incorporated carbon occurs. The fractionation factor $\epsilon$ depends on the photosynthetic pathway: $\epsilon\left(\mathrm{C}_{3}\right)=-19 \%$; $\epsilon\left(\mathrm{C}_{4}\right)=-5 \%$ (Vogel, 1993; Lloyd and Farquhar, 1994). In the $p \mathrm{CO}_{2}$ range of $180-280$ ppmv covered here the fractionation factors are independent of carbon dioxide partial pressure (Vogel, 1993). All other processes are assumed to occur without further fractionation.

We finally parameterise our model with data from literature (Table 2) which leads to a representation of the terrestrial biosphere during preindustrial times consistent with the current knowledge on carbon stocks, isotopic signature and NPP gathered in Table 1.

\section{Paleo Climate}

Besides the global area available for vegetation (which is correlated to sea level and the size of continental ice sheets), temperature, precipitation and atmospheric carbon dioxide are the most important variables which determined changes in the terrestrial biosphere on glacial/interglacial timescales. However, because we follow a globally averaged modelling approach, spatial gradients in those variables can only be considered on a phenomenologically basis. In the following we rely on temperature and $p \mathrm{CO}_{2}$ records only. Both informations can be deduced from ice cores. Since the atmosphere is a well mixed reservoir $p \mathrm{CO}_{2}$ in Antarctic ice cores is essentially a global signal. In contrast, globally averaged temperature changes are reconstructed from Arctic and Antarctic ice core isotope temperature records by weighing them according to the latitudinal distribution of land area (of which $3 / 4$ is located in the northern hemisphere if the Antarctic continent is omitted, Fig. 2).

Currently, we cannot account for local precipitation changes in our model and assume that global precipitation changes are related to temperature changes. Thus, any precipitation effect is effectively parameterised in our temperature forcing. Several studies which show a correlation in changing pattern in monsoonal climate variability and temperature fluctuations in Greenland or the North Atlantic support this approach (Schulz et al., 1998; Wang et al., 2001; 
Altabet et al., 2002; Gupta et al., 2003). However, we know about the shortcomings of local effects (e.g. Joussaume et al., 1999; Braconnot et al., 2000). Concerning southern hemispheric temperatures new data analyses give strong evidence that temperature signals deduced from Antarctic ice cores are representatitive for the pattern found in the whole Southern Ocean (Becquey and Gersonde, 2003).

One of the problems of transient simulation experiments is the existence of proxy data sets, which cover the whole simulation period and from which meaningful forcing functions can be deduced on a common time scale. We therefore rely on absolute timing and synchronisation studies whenever possible.

\subsection{Sea Level Change}

We relate the sea level change derived from coral reef terraces (Fairbanks (1990), Fig. 3A) linearly with the current knowledge on areas covered by vegetation $A_{\mathrm{LAND}}$, and land ice sheets and lakes $A_{\mathrm{ICE}}$ at the LGM and at interglacial times (Adams and Faure, 1998) and interpolate between those timeslices (Fig. 3B). Thus, we assume a maximum sea level change from LGM to Holocene of about $130 \mathrm{~m}$. Although, the global land area at the LGM is approximately $14 \times 10^{12} \mathrm{~m}^{2}$ larger than today, the effective area $A_{\mathrm{EFF}}=$ $A_{\mathrm{LAND}}-A_{\mathrm{ICE}}$ covered by vegetation is by $\sim 5 \times 10^{12} \mathrm{~m}^{2}$ smaller at the LGM than at PRE due to the increase in lakes and ice sheet advances (Fig. 3C).

\subsection{Climate Information Derived from Ice Cores}

Data from different ice core archives have their individual time scales. Because the climate information uses here is not available in the same ice core we have to use various cores, but need for our transient modelling approach a common time scale. For this purpose we rely on methane synchronisation of various ice cores (Blunier et al., 1998; Brook et al., 2000; Blunier and Brook, 2001). We choose the GISP2 to be our master time scale whenever possible (Brook et al., 1996) where dating is based on annual layer counting for the last $50 \mathrm{kyr} \mathrm{BP}$ (Meese et al., 1994, 1997).

In detail, the following archives are used:

- Atmospheric $p \mathrm{CO}_{2}$ and $\delta^{13} \mathrm{CO}_{2}$ (Fig. 3D): For a consistent picture of the carbon cycle records of both $p \mathrm{CO}_{2}$ and $\delta^{13} \mathrm{CO}_{2}$ at the same depths of one ice core are essential. Therefore, we use the carbon dioxide data of the Taylor Dome ice core (0-30 kyr BP), because this core is the only one on 
which $\delta^{13} \mathrm{CO}_{2}$ was measured over the last $29 \mathrm{kyr}$ so far (Smith et al., 1999; Indermühle et al., 2000). Taylor Dome data are plotted on the GISP2 time scale Brook et al. (2000).

- Atmospheric temperature changes (Fig. 3E): We take $\delta^{18} \mathrm{O}_{\text {ice }}$ from GISP2, Greenland (Grootes and Stuiver, 1997) and $\delta \mathrm{D}$ in the Antarctic ice core of Vostok (Jouzel et al., 1987; Petit et al., 1999) as temperature proxies. To use these isotopic informations as average hemispherical signals we rescale the amplitudes of the temperature changes between preindustrial times and the LGM. Modelling results of glacial/interglacial (G/IG) temperature changes over land (Kutzbach et al., 1998) - if weighted with latitudinal land area distribution (Fig. 2) - find a globally averaged increase of 9-10 K since the LGM. Because the land area in northern latitudes (43\% of land area in 30$90^{\circ} \mathrm{N}$ ) is approximately of the same size than those in the tropical band $(45 \%$ of land area in $30^{\circ} \mathrm{S}-30^{\circ} \mathrm{N}$ ) the temperature changes observed/modelled in these two bands are of the same importance. Kutzbach et al. (1998) proposed a $\Delta \mathrm{T}$ (LGM $-\mathrm{PRE}$ ) of about $-15 \mathrm{~K}$ and $-5 \mathrm{~K}$ for northern latitudes and tropics, respectively. The decrease at the LGM in tropical land temperature seems to be supported by various studies although variations in the Paleoclimate Modelling Intercomparison Projects (PMIP) are still large (Ganopolski et al., 1998; Farrera et al., 1999; Pinot et al., 1999). The northern temperature change, however, was estimated to be about $-10 \mathrm{~K}$ and, thus, significantly smaller in other studies (Kageyama et al., 2001; Kim et al., 2002). We rely on the latter results and arrive at a northern hemisphere temperature change amplitude of $-8 \mathrm{~K}$. We rescale the $\mathrm{G} / \mathrm{IG}$ temperature change amplitude in Vostok to a southern hemispheric average of $\Delta \mathrm{T}=-5 \mathrm{~K}$ (Kutzbach et al., 1998).

\section{Driving Forces}

In the following we document the functions which altered our terrestrial biospheric carbon stocks and which were driven by the paleo archives described in the previous section.

\subsection{Sea Level Change}

The effects of sea level changes are twofold:

First, the fractions $r_{\mathrm{LAND}}=\Delta A_{\mathrm{LAND}} / A_{\mathrm{EFF}}$ and $r_{\mathrm{ICE}}=\Delta A_{\mathrm{ICE}} / A_{\mathrm{EFF}}$ represent the relative changes in land area and in area covered with land ice sheets \& lakes, respectively. If flooding of land $\left(r_{\text {LAND }}<0\right)$ through sea level rise or a destructive advance of land ice $\left(r_{\mathrm{ICE}}>0\right)$ occurs the fractions $-r_{\text {LAND }}$ and $r_{\mathrm{ICE}}$ 
of biomass in all carbon pools are removed. The current knowledge of the fate of organic matter submerged by sea level rise or glacial advance is still limited (Hedges et al., 1997; Raymond and Bauer, 2001). Here, we assume that all terrestrial carbon destroyed by either sea level rise or ice sheet advance enters the atmosphere through decomposing processes.

The second effect of a sea level change is a modification of the steady states $C_{i}^{*}$ of the photosynthetic compartments $(i=\mathrm{C} 4, \mathrm{C} 3, \mathrm{NW})$. The potential carbon contents of these boxes are modified by the fraction of effective land area change $\left(\widetilde{C}_{i}^{*}=\left(1-r_{\mathrm{EFF}}\right) \cdot C_{i}^{*}, r_{\mathrm{EFF}}=\left(\Delta A_{\mathrm{LAND}}+\Delta A_{\mathrm{ICE}}\right) / A_{\mathrm{EFF}}\right)$.

\section{2 $\mathrm{pCO}_{2}$ Fertilisation}

Fluctuations in the atmospheric $p \mathrm{CO}_{2}$ concentration affect different ecosystems in different ways (Körner, 2000). There are evidences that an increase in $p \mathrm{CO}_{2}$ will enhance NPP, but the increase in carbon sequestration seems to depend on soil fertility and not on $p \mathrm{CO}_{2}$ (Gill et al., 2002). For net ecosystem productivity (NEP) temperature dependence of the heterotrophic respiration might be more important than the fertilisation effect (Valentini et al., 2000; Schlesinger and Lichter, 2001). Models of the terrestrial biosphere indicate that $p \mathrm{CO}_{2}$ fertilisation is necessary to some extent to explain observed recent carbon fluxes (Friedlingstein et al., 1995a).

We follow those evidences of the experiments and modify only the net primary production NPP (by multiplying the growth rate $\nu_{i}$ with a fertilisation factor $f_{\mathrm{CO}_{2}}^{\mathrm{NPP}}(t)=1+\gamma(t)$, for $\gamma$ see Eq. 4.1) and not the steady state values.

To allow comparison with previous studies we choose a logarithmic fertilisation function $\gamma(t)$ (Harvey, 1989; Kicklighter et al., 1999).

$$
\gamma(t)=\beta \cdot \ln \left(\frac{p \mathrm{CO}_{2}(\mathrm{t})}{p \mathrm{CO}_{2}\left(t_{0}\right)}\right)
$$

with $p \mathrm{CO}_{2}\left(t_{0}\right)=280$ ppmv for the interglacial carbon dioxide partial pressure.

\subsection{Temperature Dependent Metabolic Functions}

Changes in temperature are usually accompanied by modified precipitation patterns. Thus, a prolonged growing season in high latitudes will probably increase NPP, while water stress might reduce productivity in low latitudinal regions. Additionally, soil respiration is thought to increase with temperature 
(Grace, 1991; Freeman et al., 2001). Shifts in species abundances might occur as a result of both climate and $p \mathrm{CO}_{2}$ changes (Collatz et al., 1998). We discuss the latter in the next subsections.

It is especially difficult to model those aspects in our very simplistic box model. We allow NPP and respiration to vary with temperature $T$ (Eq. 4.2). The so-called $Q_{10}$ factor, first developed by Van't-Hoff (1898), covers metabolic changes of any function $M$ through a temperature increase of $10 \mathrm{~K}$ :

$$
M=M_{0} \cdot Q_{10}^{\frac{\Delta T}{10}}
$$

Our temperature proxy record (Fig. 3E) gives no absolute temperature, but only changes $\Delta T$. Therefore, we assume no temperature effects for preindustrial times with $\Delta T \approx 0 \mathrm{~K}$. Harvey (1989) analysed various $Q_{10}$ value. First, we adopt his values of $Q_{10}^{\mathrm{C} 4}=1.4$ and $Q_{10}^{\mathrm{C} 3}=2.0$ for the dependences of $\mathrm{C}_{3}$ and $\mathrm{C}_{4}$ photosynthesis and $Q_{10}^{\mathrm{RES}}=2.0$ for respiration and then determine consistent values in a sensitivity analysis. In detail, the $Q_{10}$ factor is applied to the growth functions $\nu_{i}$, the steady-state solutions $C_{i}^{*}$ (and via its functional dependencies also to $\rho_{i}$ ), and all fluxes of respiration and transfers to soil compartments $\alpha_{i j}$.

Instead of considering variability in NPP this $Q_{10}$ factor might be applied to gross primary production and autotrophic respiration, which both might have different temperature dependencies. Because paleoinformations on those are even rarer than on NPP and to keep the model as simple as possible we remain with the given variability of our production processes.

\subsection{Shifts in $C_{3} / C_{4}$ Abundance}

The abundances of $\mathrm{C}_{3}$ and $\mathrm{C}_{4}$ plants influence the isotopic signature of the atmospheric carbon. There is increasing evidence that not only $p \mathrm{CO}_{2}$ but also temperature controls this species distribution (Collatz et al., 1998; Boom et al., 2002). Therefore, we adopt a function developed by Collatz et al. (1998) which calculates the cross-over temperature $T_{50}=f\left(p \mathrm{CO}_{2}\right)$ at which the quantum yield for photosynthetic $\mathrm{CO}_{2}$ fixation is equal for $\mathrm{C}_{3}$ and $\mathrm{C}_{4}$ photosynthesis (Fig. 4, Table 3):

$$
T_{50}\left({ }^{\circ} \mathrm{C}\right)=\frac{10}{\ln Q_{10}} \ln \left(\frac{p \mathrm{O}_{2}\left(1+0.5 \frac{\alpha_{C 3}}{\alpha_{C 4}}\right)}{0.8 \cdot p \mathrm{CO}_{2} \cdot s_{25}\left(\frac{\alpha_{C 3}}{\alpha_{C 4}}-1\right)}\right)+25
$$

We compare differences in temperature change $\Delta T$ and cross-over temperature 
change $\Delta T_{50}$ between interglacial $\left(t_{0}\right)$ and current times $(t)$ and modify the steady state biomass of $\mathrm{C} 3$ and $\mathrm{C} 4$ as

$$
\begin{aligned}
& \widetilde{C_{\mathrm{C} 4}^{*}}=C_{\mathrm{C} 4}^{*} \cdot\left(1-a_{\mathrm{C} 3 / \mathrm{C} 4} \cdot\left(\Delta T-\Delta T_{50}\right)\right), \\
& \widetilde{C_{\mathrm{C} 3}^{*}}=C_{\mathrm{C} 3}^{*} \cdot\left(1+a_{\mathrm{C} 3 / \mathrm{C} 4} \cdot\left(\Delta T-\Delta T_{50}\right)\right) .
\end{aligned}
$$

We estimate the amplitude modulation factor $a_{\mathrm{C} 3 / \mathrm{C} 4}$ from sensitivity studies.

This approach might be questioned by recent findings which indicate that local moisture conditions might be of similar importance than temperature and $p \mathrm{CO}_{2}$ in controlling the $\mathrm{C}_{3}$ and $\mathrm{C}_{4}$ plant abundance (Huang et al., 2001).

\subsection{Grassland/Forest Succession}

There is evidence of a shift in the tree-line to higher latitudes with increasing temperatures (Keeling et al., 1996; Myneni et al., 1997; Crucifix and Loutre, 2002). Furthermore, shifts from grassland to forest are well correlated with climate in a case study in North America (Whitlock and Bartlein, 1997). On the other hand, atmospheric $p \mathrm{CO}_{2}$ concentrations seem to be a more important trigger than temperature for tree-line shifts in tropical montane forests (Jolly and Haxeltine, 1997; Street-Perrott et al., 1997). Recent findings of the successional shift from grasslands to woody plants question the overall effects on the ecosystem carbon storage capacity which seems to depend on precipitation (Jackson et al., 2002). Since a general relationship of grassland/forest succession as function of temperature and $p \mathrm{CO}_{2}$ was not proposed so far, we restrict successional change to depend on our temperature proxy. We implement this succession from grassland to forest by a phenomenological function which alters the steady state values of our photosynthetic compartments as a function of temperature change:

$$
\begin{aligned}
\widetilde{C_{\mathrm{X}}^{*}} & =C_{\mathrm{X}}^{*} \cdot\left(1-a_{\mathrm{G} / \mathrm{F}} \cdot(\Delta T)\right), \text { with } \mathrm{X} \in[\mathrm{C} 3, \mathrm{C} 4] \\
\widetilde{C_{\mathrm{NW}}^{*}} & =C_{\mathrm{NW}}^{*} \cdot\left(1+a_{\mathrm{G} / \mathrm{F}} \cdot(\Delta T)\right) .
\end{aligned}
$$

Again, the amplitude modulation factor $a_{\mathrm{G} / \mathrm{F}}$ has to be determined from parameter variations.

It should be noted that recent research highlighted that multi-factor ecosystem responses to climate change differ from combinations of single-factor responses (Shaw et al., 2002). 


\section{Results}

\subsection{Model Analysis}

For an increasing understanding of our model we perform a one-factor-ata-time sensitivity analysis (Daniel, 1973) of all basic parameters for typical interglacial conditions. The model is initialised with all carbon stocks $\mathrm{C}=$ $0.1 \mathrm{PgC}, \delta^{13} \mathrm{C}=0 \%$ and run for 10,000 years. We vary each parameter six to nine times in a physically consistent range, typically covering $\pm 30 \%$ of the standard values. The carbon budget and the $\delta^{13} \mathrm{C}$ of all boxes, total terrestrial carbon content, average $\delta^{13} \mathrm{C}$ and NPP are observed for their sensitivity in response to the parameter variations. We take the coefficient of variance of each output variable for the different simulations as indicator of sensitivity (Fig. 5).

The most striking results is the large influence of the turnover time $\tau_{\mathrm{NW}}$ and the steady state $C_{\mathrm{NW}}^{*}$ of the non-woody parts of trees on the carbon content of nearly all tree and soil boxes. Furthermore, the recovery times $t^{\mathrm{R}}$ do not determine long-term results, but they might be important if external timedependent forcings are applied.

In the equilibrium of the preindustrial standard case (scenario PRE steady state, Table 4) the total terrestrial carbon contains $2174 \mathrm{PgC}$ consisting of 669 and $1504 \mathrm{PgC}$ of vegetation and soil carbon, respectively, whereby the partitioning of soil carbon in reservoirs of different turnover times $(251,1090$ and $163 \mathrm{PgC}$ for detritus, fast and slow decomposing soils, respectively) is based on studies of Schimel et al. (1994); Falloon et al. (1998). The photosynthetic compartments $\left(34,27,40 \mathrm{PgC}\right.$ for $\mathrm{C}_{4}, \mathrm{C}_{3}$ ground vegetation, nonwoody, respectively) are of similar size, but woody parts of trees (568 $\mathrm{PgC}$ ) are about 10\% smaller than in previous model applications (Harvey, 1989; Kheshgi et al., 1996). Thus, the preindustrial carbon stocks and primary productivity $\left(\mathrm{NPP}=58 \mathrm{PgC} \mathrm{yr}^{-1}\right)$ lie well within the middle of our target ranges defined from the literature survey (Table 1 ). The fraction of $\mathrm{C}_{4}$ material is 20\%, very close to the results of François et al. (1998).

Besides the steady states the dynamical model behaviour will be important for a time-dependent transition experiment. During model spin-up (Fig 6) the vegetation compartments reach $99 \%$ of their equilibrium values after about 40 and 200 years, but it takes 500 and 4800 years to steady state for the fast and slow decomposing soils. Even more important, the equilibrium times for the isotopic signatures are well below one century for the vegetation boxes and longest for the slow decomposing soil (about 800 years). However, the carbon content of the latter box is small. 


\subsection{Climate forcing at the LGM}

Six control parameters emerge from the definition of our driving forces (Table 2). While some of them are used in previous studies (e.g. $\beta$ or $Q_{10}$ factor), others are technical parameters $\left(a_{\mathrm{C} 3 / \mathrm{C} 4}, a_{\mathrm{G} / \mathrm{F}}\right)$, whose appropriate values need to be determined in sensitivity experiments. Furthermore, the forcing through sea level change is deterministic without a tunable parameter, but leads only to small changes of $3-4 \%$ in the carbon content of all boxes and to no changes in the isotopic signatures.

We first analyse separately what effects the different forcing mechanisms have on the simulated biosphere. Later, the full range of possible control parameters is investigated. For this purpose, we drive steady state simulations over 10,000 years with different forcing strength for the LGM and then evaluate and compare them with our literature targets.

\subsubsection{Effects of individual driving forces}

$p \mathrm{CO}_{2}$ fertilisation: Glacial $p \mathrm{CO}_{2}$ levels decrease total carbon linearly with increase in the control parameters $\beta$ (Fig. 7A). At $\beta>0.3$ tree growth collapses as respiratory losses are not covered by the growth rates $\nu_{i}$ anymore leading to a minimum total carbon of about $500 \mathrm{PgC}$.

This result shows, that $p \mathrm{CO}_{2}$ fertilisation invoked in previous studies on recent climate change $(\beta=0.287$ in Kicklighter et al. (1999), $\beta=0.42$ in Kheshgi et al. (1996)) are not directly transferable on problems of glacial/interglacial timescales. Even if our and their model architectures are very similar, they influence simulation results and need to be considered in comparisons.

Successional changes: Succession solely between $\mathrm{C}_{3}$ and $\mathrm{C}_{4}$ ground vegetation $\left(a_{\mathrm{G} / \mathrm{F}}=0\right)$ induced through both temperature and $p \mathrm{CO}_{2}$ changes increases the overall $\mathrm{C}_{4}$ fraction to $24 \%$ (Fig. $7 \mathrm{~B}$ ). If temperature induced grassland/forest succession is also considered $\left(a_{\mathrm{G} / \mathrm{F}}>0\right)$ this fraction rises to $42 \%$. With highest amplitude modulation of grassland/forest succession the total carbon and carbon bound in forests decrease both by $300 \mathrm{PgC}$.

Direct effects of temperature change: While the impact of $Q_{10}^{\mathrm{C} 4}$ is of minor importance, the metabolic changes in respiration and $\mathrm{C}_{3}$ photosynthesis need to be considered together, otherwise biospheric carbon stocks vary over a wide range. (Fig. 7C). If $Q_{10}^{\mathrm{C} 3}$ and $Q_{10}^{\mathrm{RES}}$ vary widely either tree growth collapses $\left(Q_{10}^{\mathrm{C} 3}>>Q_{10}^{\mathrm{RES}}\right)$ or terrestrial carbon at LGM is larger than at preindustrial times $\left(Q_{10}^{\mathrm{C} 3}<<Q_{10}^{\mathrm{RES}}\right)$.

This separate analysis of possible effects on the biosphere demonstrates that 
the choice of the control parameters can force the simulated system over a wide range of possible LGM states, which easily cover our carbon target intervals defined by our literature survey. However, if all available information (carbon content, primary production, isotopic signatures) are used to assess the different scenarios it becomes clear that only an interplay of all forces is able to generate LGM states which fulfil all requirements. We, therefore, investigate in the following the simulation results of a systematic sensitivity analysis which covers plausible ranges of all control parameters. However, we are aware that during the LGM only carbon content estimates are based on data sets while our other informations (primary production, isotopic signatures) are mostly based on other modelling results and thus should used with caution as secondary constraints, only.

\subsubsection{Interplay of all forcings}

We test our model with climate forcing strengths used before (Kheshgi et al., 1996; Kicklighter et al., 1999). It clearly evolves that they lead to unrealistic LGM states (Table 4). In the Kheshgi scenarios a very strong $\mathrm{CO}_{2}$ fertilisation is compensated by $\mathrm{Q}_{10}$ temperature dependencies which would favour biospheric growth at LGM conditions. The Kicklighter forcing consisting only of $\mathrm{CO}_{2}$ fertilisation leads to a LGM vegetation which contains hardly any trees.

Consecutively, the parameters controlling the climate forcings are varied simultaneously in their realistic range (Table 2) leading to about 10,000 different states in the six-dimensional parameter space (Table 4). Total biospheric carbon at LGM varies between 336-4149 $\mathrm{PgC}$ with a mean of $1555 \pm 843 \mathrm{PgC}$, the fraction of $\mathrm{C}_{4}$ material $f_{\mathrm{C} 4}$ between $7-80 \%(34 \pm 19 \%)$ and NPP from 7 to $95(35 \pm 21) \mathrm{PgC} \mathrm{yr}^{-1}$. Thus, average values already fall in the target ranges. If additionally one or several literature targets (carbon stocks $\mathrm{C}$, fraction of $\mathrm{C}_{4}$ material $f_{\mathrm{C} 4}, \mathrm{NPP}$ ) act as filter on our results, the relative errors can be reduced from about $55 \%$ to below $10 \%$. The average terrestrial carbon is remarkable stable around $1600 \mathrm{PgC}$ (Fig. 8). Here, only $f_{\mathrm{C} 4}$ deviates from this general pattern. By the filter procedure the number of considered scenarios is reduced to $1 \%$ of the original calculations if all three targets were applied simultaneously.

\subsubsection{Sensitivity to different climate change}

We finally select from those target fulfilling scenarios those (case I) whith $p \mathrm{CO}_{2}$ fertilisation of moderate intensity which is $\left(\Delta \mathrm{C} / \Delta p \mathrm{CO}_{2} \sim 4-5 \mathrm{PgC} / \mathrm{ppmv}\right)$ similar to a recent DGVM study (Gerber et al., 2003) and (case II) with lower $p \mathrm{CO}_{2}$ fertilization than in the first case. Case II is chosen since $p \mathrm{CO}_{2}$ in 
case I could account alone for almost the whole glacial/interglacial biospheric carbon change, which seems to be very unlikely. The fertilization is equivalent to $\beta=0.1$ (I) and $<0.1$ (II). The selection of parameter combinations in case I and II is further based on the individual performance with respect to both temperature and $p \mathrm{CO}_{2}$ changes. Thus, scenarios in which an unrealistic strong response to one climate variable is compensated by the other are rejected from our selection. We end up with only 14 and 12 scenarios from the initial sets for the two cases. We then vary climate in terms of $p \mathrm{CO}_{2}$, temperature and sea level over the whole range observed between LGM and preindustrial times and calculate the steady state system responses of the forcings (Fig. 9).

The forcings in temperature $\left(p \mathrm{CO}_{2}\right.$ fertilisation) are approximately of double (halve) the strength between the two cases. The relative effect on biospheric carbon is up to 30 and $60-70 \mathrm{PgC} / \mathrm{K}$ for a global temperature change up to $10 \mathrm{~K}$ in case I and II, respectively (Fig. 9C,D). The $p \mathrm{CO}_{2}$ fertilisation effect for reductions in carbon dioxide of up to $100 \mathrm{ppmv}$ leads to a decrease in terrestrial carbon stocks of about 2.5 or $5 \mathrm{PgC} / \mathrm{ppmv}$ (case I or II, Fig. 9A,C). A drop in sea level leads to a constant decline in carbon of $\sim 0.7 \mathrm{PgC} / \mathrm{m}$ (Fig. $9 \mathrm{E}$ ).

\subsection{Termination I}

We finally simulate the changes in terrestrial carbon storage during Termination I in the transition from the LGM to the Holocene. We restrict this experiment to the cases I and II of our climate change forcings. Simulations are started at $30 \mathrm{kyr} \mathrm{BP}$ and initialised with all terrestrial stocks at $\mathrm{C}=0.1$ $\mathrm{PgC}, \delta^{13} \mathrm{C}=0 \%$ and forced with our climate change records. According to our initial dynamical studies the system should reach the a state in line with climate forcing after $5 \mathrm{kyr}$. Thus, simulation results of the terrestrial carbon stock are plotted from 25-0 kyr BP, only (Fig. 10). To compare our transient simulation results with the time-dependent forcings the latter are plotted on a normalised scale in the same figures.

Depending on the different forcings the terrestrial carbon stock follows more the changes in atmospheric $\mathrm{CO}_{2}$ (case I, Fig. 10A) or temperature (case II, Fig. 10B). The uncertainties for the LGM states at around $20 \mathrm{kyr}$ BP are still large $(100-150 \mathrm{PgC})$ but smaller in the temperature dominated case II. Even in the $\mathrm{CO}_{2}$ dominated case I the Bølling/Allerød-Younger Dryas (BAYD) climate oscillation in the northern hemisphere (14-12 kyr BP) causes a temperature induced peak in biospheric carbon. However, in case I this peak was only followed by a small decline $(50 \mathrm{PgC})$ in the terrestrial stock while $200 \mathrm{PgC}$ are lost thereafter in case II. In all results biospheric carbon is not enhanced at around $6 \mathrm{kyr} \mathrm{BP}$, which is known as the mid Holocenic climate optimum. The effective impacts of sea level changes are about $4 \%$ land area 
change over the whole termination and are of minor importance.

\section{Discussion}

Simple terrestrial biosphere box models were used before on recent climate change problems (e.g. Kheshgi et al., 1996; Kicklighter et al., 1999; Randerson et al., 2002), and seldomly for the interpretation of paleorecords (Indermühle et al., 1999; Joos et al., 1999a; Marchal et al., 1999). In the latter cases climate changes did not force dynamics of the terrestrial biosphere via physiological functions as done here. Instead the carbon fluxes to/from the land biota were calculated by inverse methods from a simple ocean-atmosphere model (Bruno and Joos, 1997; Joos and Bruno, 1998). Most paleoclimatic approaches which try to explain the fluctuations in the atmospheric $p \mathrm{CO}_{2}$ were focused on the ocean and the terrestrial biosphere was either ignored (e.g. Toggweiler, 1999) or considered phenomenologically (e.g. Archer et al., 2000). Especially in transient modelling experiments a good constraint of the carbon fluxes from/to the terrestrial biosphere will reduce this major uncertainty.

How reliable is the extrapolation of the model application range from the so far tested time frame of recent decades or centuries to glacial timescales of thousands of years? The choice of our basic parameters (Table 2) leads to a preindustrial steady state which is well supported by other studies. Especially the content and distribution of soil carbon to reservoirs of different turnover times is validated with field observations and modelling estimates (Schimel et al., 1994; Batjes, 1996; Falloon et al., 1998). It should be noted that soil organic matter is normally defined by the content of the upper $100 \mathrm{~cm}$ of the soil, but that the amount of carbon in deeper soil might be of the same order of

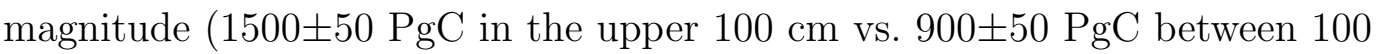
and $200 \mathrm{~cm}$ (Batjes, 1996)). The constraints given by the additional boundary conditions for NPP and especially the isotopic signature lead to about $60 \mathrm{PgC}$ in ground vegetation and $610 \mathrm{PgC}$ in trees. It is difficult to compare those values with other approaches since normally biomes and not different plant functional types like trees and ground vegetation are distinguished. In the pollen data based approach of Adams and Faure (1998) the grassland dominated ecosystems bound on average $77 \mathrm{PgC}$, forest stocks contained $827 \mathrm{PgC}$ of the potential vegetation at present; the modelling study of François et al. (1998) led to $600 \mathrm{PgC}$ of carbon in forests and $21 \mathrm{PgC}$ in grasslands. Most other studies already contained anthropogenic influences such as forest clearing (e.g. Dixon et al., 1994; FAO, 2001). Hall and Scurlock (1991) find about $25 \mathrm{PgC}$ in tropical grasslands alone and give us reasons to believe that the grassland carbon stocks in François et al. (1998) might be too small. Furthermore, the importance of peat as a potential carbon sink on glacial timescales as indicated by Adams and Faure (1998) is difficult to assess. Recent estimates 


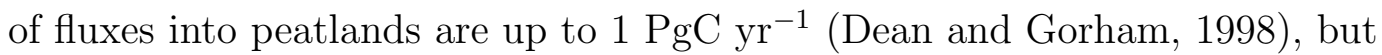
the organic carbon content of peat depends strongly on temperature (Freeman et al., 2001) and water table (e.g. Wösten et al., 1997). Again, the considered depth of the peat layer is important. Gorham (1991) estimated the recent carbon content of northern peatland to $455 \mathrm{PgC}$ with an average depth of $2.3 \mathrm{~m}$. Restricting informations on carbon stocks by additional informations about their isotopic signatures - as done here - seems to be a suitable approach which combines the currently available knowledge about the terrestrial biosphere to a consistent picture with reduced uncertainties.

Are our proposed forcing functions reasonable? From the sensitivity study we learn that the forcing strength of similar box models imposed by recent climate change studies are not directly transferable to questions of glacial/interglacial times. In the study of Kicklighter et al. (1999) only $\mathrm{CO}_{2}$ fertilisation was investigated. Thus, their $\beta$ value left no space for temperature driven metabolic changes. Only a weak $\mathrm{CO}_{2}$ fertilisation was also proposed by a former simulation study (Peng et al., 1995) and model sensitivity to $p \mathrm{CO}_{2}$ is of similar magnitude (case I) than in a DGVM study on the variability of the last millennium (Gerber et al., 2003). The temperature dependent metabolic control parameters in our study are smaller than in previous ones. We finally use for all three $Q_{10}$ factors values between 1.1 and 1.5 while formerly $Q_{10}>2.0$ was proposed (Raich and Schlesinger, 1992). In a recent biospheric box model approach the $Q_{10}$ factor of respiration processes was found to be 1.52 (Randerson et al., 2002). Since they investigated seasonal temperature fluxes this is not directly comparable to our study. Our $Q_{10}$ factors lead in both simulation cases to a reduction in biospheric carbon with decreasing temperature. We would therefore not be able to simulate an increasing biosphere during the Little Ice Age (at about 1500 yr AD) due to reduced soil respiration by a temperature drop of about $1 \mathrm{~K}$, as found in other studies (Trudinger et al., 1999; Joos et al., 1999a; Gerber et al., 2003). It becomes clear that for this kind of dynamics our model is too simple in terms of resolution and considered processes.

A reason for the fast system response to temperature changes especially in case II appears to be the fact that the grassland/forest succession is driven without any time delay by the temperature changes. Especially a change from grassland to forest should be delayed by several years or decades. For investigations on forest clearing Emanuel et al. (1984) introduced a time delay until forest dominance of $\kappa=5$ years in the predecessor of our model. Since climate fluctuations are resolved only on the order of decades to centuries a $\kappa$ of similar length would not lead to large changes here.

Our model suggests that terrestrial carbon stocks at the LGM are around 1600 PgC. However, because the constraints on NPP and the fraction of $\mathrm{C}_{4}$ plants were based on only a few mostly modelling studies, we merely interprete those as a model evaluation. It should be especially noted that the estimated 
LGM terrestrial carbon is already reached without LGM target ranges, but uncertainty is reduced significantly by the use of additional filters. Such a filtering procedure is a widely used approach of reducing uncertainty and revealing hidden informations in pattern-oriented spatially explicit population models (e.g. Wiegand et al., 2003a,b).

No maximum terrestrial carbon stock is reached during the mid Holocene (6 kyr BP) in our model, although climate conditions are believed to have favoured biospheric growth due to warmer northern continents and enhanced monsoons (Foley, 1994; Indermühle et al., 1999). The reason for this is the lack of a clear temperature maximum in our northern hemispheric temperature proxy deduced from the GISP2 record. This shows only $0.5-1.0 \mathrm{~K}$ warmer temperatures at $6 \mathrm{kyr} \mathrm{BP}$ compared to preindustrial times and does not reflect the more than $2 \mathrm{~K}$ increase over most northern latitudes derived from paleodata and modelling (Foley, 1994; TEMPO, 1996; Texier et al., 1997). Also these studies emphasize the importance of regional differences, e.g. cooling over tropical regions and changes in precipitation and monsoon pattern (Joussaume et al., 1999). Since our forcing data sets do not include the commonly believed climate trends during the Holocene we test the model with past temperatures derived from borehole measurements at GRIP, Greenland (Dahl-Jensen et al., 1998). Those measurements found a G/IG temperature amplitude in Greenland of $23 \mathrm{~K}$ and the Holocene between 8 and $5 \mathrm{kyr}$ BP was about $2.5 \mathrm{~K}$ warmer than during preindustrial times. While in simulations of the $\mathrm{CO}_{2}$ dominated case I no significant differences to results achieved with the GISP2 derived temperature forcing are resolved, the biosphere increases to its maximum around $5 \mathrm{kyr} \mathrm{BP}$ and then releases $50 \mathrm{PgC}$ thereafter in case II. These Holocene dynamics are smaller than the late Holocene biospheric release fluxes of 100 and $200 \mathrm{PgC}$ proposed by Brovkin et al. (2002a) and Indermühle et al. (1999). Because data constraints from ice cores and ocean sediments come to conflicting interpretations of the causes of atmospheric carbon dynamics (Smith et al., 1999; Broecker et al., 2001; Fischer et al., 2003) the value of our modelling results on this specific period is difficult to judge. We feel that the model presented here is not able to account for these effects adequately.

In this context it should be noted that in a modelling study the terrestrial carbon stock was insensitive to a $30 \%$ reduction in global precipitation and temperature effects and moderate $p \mathrm{CO}_{2}$ fertilisation were identified as most likely drivers of G/IG changes (Peng et al., 1995). This implies that regional differences in precipitation and not global average changes are of importance on paleoclimatic time scales.

Because atmospheric $p \mathrm{CO}_{2}$ and $\delta^{13} \mathrm{CO}_{2}$ are given data constraints from ice cores and changes in terrestrial carbon stocks are calculated in our model the resulting carbon fluxes of the ocean into the atmosphere/biosphere subsystem 
can be calculated by the following mass balance equations:

$$
\begin{aligned}
\frac{d \mathrm{C}_{\mathrm{o}}}{d \mathrm{t}} & =\mathrm{C}_{\mathrm{b} 2 \mathrm{a}}-\mathrm{C}_{\mathrm{a} 2 \mathrm{~b}}-d \mathrm{C}_{\mathrm{a}} \\
\frac{d \delta^{13} \mathrm{C}_{\mathrm{o}}}{d \mathrm{t}} & =\left(\mathrm{C}_{\mathrm{b} 2 \mathrm{a}} \cdot \delta^{13} \mathrm{C}_{\mathrm{b} 2 \mathrm{a}}-\mathrm{C}_{\mathrm{a} 2 \mathrm{~b}} \cdot \delta^{13} \mathrm{C}_{\mathrm{a} 2 \mathrm{~b}}-d \mathrm{C}_{\mathrm{o}} \cdot \delta^{13} \mathrm{C}_{\mathrm{o}}-\left(d \mathrm{C}_{\mathrm{a}} \cdot \delta^{13} \mathrm{C}_{\mathrm{a}}+\mathrm{C}_{\mathrm{a}} \cdot d \delta^{13} \mathrm{C}_{\mathrm{a}}\right)\right) / \mathrm{C}_{\mathrm{o}}
\end{aligned}
$$

with the subscripts o, a, b, for oceanic, atmospheric, and biospheric reservoirs. Note, that for the calculation of the changes in the isotopic signal of the ocean the fluxes from/to the biosphere (respiration $\mathrm{C}_{\mathrm{b} 2 \mathrm{a}}$ and $\mathrm{NPP} \mathrm{C}_{\mathrm{a} 2 \mathrm{~b}}$ ) are of importance. Since they might carry a different $\delta^{13} \mathrm{C}$ signal additional information might be gained from these annual fluxes, while for the oceanic $\mathrm{C}$ budget the net increase of the terrestrial stocks is sufficient. For this exercise, we adopt a DIC pool $\left(\mathrm{C}_{\mathrm{o}}\right)$ of $38,800 \mathrm{PgC}$ and $\delta^{13} \mathrm{C}(\mathrm{DIC})=0.0 \%$ for the LGM. The ocean releases about 750-800 $\mathrm{PgC}$ during the transition, from which a fourth stays in the atmosphere and $3 / 4$ cumulates in the terrestrial stocks (Fig. 11A). During the transition the dynamics in atmospheric $p \mathrm{CO}_{2}$ are in phase with the overall release from the oceans which is expected because the biospheric growth is partly driven by $\mathrm{CO}_{2}$ partial pressure. This additional carbon flux from the ocean to the terrestrial biosphere has always to be considered for the explanation of the observed $\mathrm{G} / \mathrm{IG}$ changes in atmospheric $p \mathrm{CO}_{2}$. Modelling studies of ocean box models especially for the BA-YD time period need to account for a carbon release which would in general be four times greater than the observed atmospheric dynamics (Marchal et al., 1998). In that way changes in the atmosphere would be amplified by the terrestrial growth to yield the overall oceanic release.

The dynamics of the carbon isotopic signature is more complicated (Fig. 11B). Oceanic inorganic carbon is becoming $0.4 \%$ heavier during the $\mathrm{G} / \mathrm{IG}$ transition, which is in good agreement with both modelling studies and data constraints (Curry et al., 1988; Duplessy et al., 1988; Michel et al., 1995). It should be noted that $85 \%$ of this calculated oceanic change in $\delta^{13} \mathrm{C}$ can be explained by the increase in the terrestrial carbon stock and only the missing fraction of $15 \%$ by changes in the abundance of the two photosynthetic pathways. Thus, uncertainties in the current knowledge on $\mathrm{C}_{3} / \mathrm{C}_{4}$ plant distribution during the LGM are of minor importance for the overall simulation results. Even if the dynamics in atmospheric $\delta^{13} \mathrm{CO}_{2}$ seems to follow the ocean release especially during late transition (15-10 kyr BP) most of the dynamics in the oceanic carbon isotopic signature are due to the carbon exchange between the biosphere and the ocean. This implies that climate impacts on atmospheric $p \mathrm{CO}_{2}$ and $\delta^{13} \mathrm{CO}_{2}$ during the transition are different: While $p \mathrm{CO}_{2}$ is mainly controlled by oceanic processes, the terrestrial biosphere has significant influence on the carbon isotopic signature.

The regrowth of the terrestrial biosphere during the last $21 \mathrm{kyr}$ was sim- 
ulated recently with the Lund-Potsdam-Jena-DGVM (Kaplan et al., 2002). Even if their model is a highly sophisticated state-of-the-art dynamic vegetation model, its application in a transient simulation bears considerable problems. Climate states were prescribed from a general circulation model in $1 \mathrm{kyr}$ intervals. This implies that fast climate fluctuations like the BA-YD are not resolved in their representation of paleoclimate and, thus, are not reflected in the DGVM results. Furthermore, their results imply a shift in marine $\delta^{13} \mathrm{C}$ of $0.6 \%$ which is about $50 \%$ larger than the data constraints. Thus, the G/IG increase in terrestrial carbon of $821 \mathrm{PgC}$ proposed by them is probably too large. It is remarkable that $237 \mathrm{PgC}$ of this terrestrial increase appear during the Holocene, which conflicts with recent interpretation of the atmospheric carbon records. A combination of our simple approach which allows complex sensitivity analysis with their regionalised complex model seems to be a promising step towards an understanding of G/IG dynamics of the terrestrial biosphere.

Discussing the causes of oceanic carbon release is beyond the scope of this biosphere onlys̈tudy. We only want to highlight that the dynamics in $\delta^{13} \mathrm{C}$ presented here corresponds to analysis of atmopsheri $\mathrm{CO}_{2}$ and $\delta^{13} \mathrm{C}$ from the Taylor Dome ice core (Smith et al., 1999; Fischer et al., 2003). From simple assumptions it seems that the ocean was the dominant driver of the dynamics during the transition, while the biospheric growth dominated the more stable times of the LGM and the Holocene. However, since those calculations are based on steady state assumptions of the ocean and considered a two box system (biosphere against atmosphere/ocean) they are of limited meaning for the transition time. Because the dynamics in the atmospheric carbon isotope record and the oceanic release are remarkable different during LGM and Holocene but in qualitative agreement during the termination (Fig. 11B) our study points in the same direction. The mismatch of our results for the Holocene was discussed above and it seems that during these relatively small scale changes during stable periods (LGM, Holocene) some processes not resolved in our model or in the proxy data are dominant. Furthermore, the carbon isotopic minimum at the beginning of the glacial termination (here around $17.5 \mathrm{kyr} \mathrm{BP}$ ) was recently attributed to a response to Southern Ocean stratification processes (Spero and Lea, 2002) and thus a result of ocean dynamics.

It is difficult to come to a conclusion whether simulations of case I or II are more likely. From the Holocenic analysis the temperature dominated case II seems to be more appropriate, but then $\mathrm{CO}_{2}$ fertilisation would be much weaker than in other studies (Gerber et al., 2003). On the other hand the Younger Dryas would result in a probably unrealistic massive terrestrial carbon loss if temperature forcing dominates the transition time. Furthermore, not only is our model very simplistic, the forcing depends on only a few paleorecords amd their respective time scale. The extrapolation from single ice cores to whole hemispheres might exaggerate local effects. For example, the 
timing of the Antarctic Cold Reversal was about 1 kyr later in the Byrd ice core than in data from Vostok as taken here (Blunier et al., 1998). However, since southern hemispheric temperature plays only a minor role in our forcing functions results are not largely effected by the choice of the Antarctic ice core. We therefore think, some general trends in G/IG dynamics can be understood with our approach but deciphering the causes and effects of individual short periods is questionable.

There are various ways to improve the current approach. Randerson et al. (2002) used a similar model and divided the land vegetation in eight different basis regions and provided different forcings for each geographic region. This might increase our understanding of the strength of temperature forcings, but on glacial scales it seems difficult to validate results for individual areas. The model certainly has to be coupled to an ocean box model of similar resolution. The carbon fluxes between atmosphere-biosphere and atmosphere-ocean and the isotopic fractionation factors of those exchanges are of the same order of magnitude. Accordingly, the biosphere module presented here incoporated in a global carbon cycle model might be useful for the interpretation of $\delta^{13} \mathrm{C}$ in atmospheric carbon dioxide in Antarctic ice cores. This might also add value and information to inverse modelling approaches and might reduce their uncertainties (LeGrand and Alverson, 2001).

\section{Acknowledgments}

We thank R.E. Zeebe, D.A. Wolf-Gladrow, J. Schmitt, I.C. Prentice, L. François and two anonymous reviewers for valuable comments on this or earlier versions of the manuscript. The project was funded by the German Secretary of Education and Research within the German climate research program DEKLIM.

\section{References}

Adams, J. M., Faure, H., 1998. A new estimate of changing carbon storage on land since the last glacial maximum, based on global land ecosystem reconstruction. Global and Planetary Change 16-17, 3-24.

Adams, J. M., Faure, H., Faure-Denard, L., McGlade, J. M., Woodward, F. I., 1990. Increases in terrestrial carbon storage from the last glacial maximum to the present. Nature 348, 711-714.

Altabet, M. A., Higginson, M. J., Murray, D. W., 2002. The effect of millenial-scale changes in Arabian Sea denitrification on atmospheric $\mathrm{CO}_{2}$. Nature 415, 159-162.

Archer, D., Winguth, A., Lea, D., Mahowald, N., 2000. What caused the glacial/interglacial atmospheric $\mathrm{pCO}_{2}$ cycles? Reviews of Geophysics 38 (2), 159189. 
Batjes, N. H., 1996. Total carbon and nitrogen in the soils of the world. European Journal of Soil Science 47, 151-163.

Becquey, S., Gersonde, R., 2003. A 0.55-Ma paleotemperature record from the Subantarctic zone: implications for the Antarctic Circumpolar Current development. Paleoceanography 18, 1014, doi: 10.1029/2000PA000576.

Bird, M. I., Lloyd, J., Farquhar, G. D., 1994. Terrestrial carbon storage at the LGM. Nature 371, 566.

Blunier, T., Brook, E. J., 2001. Timing of millennial-scale climate change in Antarctica and Greenland during the last glacial period. Science 291, 109-112.

Blunier, T., Chappellaz, J., Schwander, J., Dällenbach, A., Stauffer, B., Stocker, T. F., Raynaud, D., Jouzel, J., Clausen, H. B., Hammer, C. U., Johnsen, S. J., 1998. Asynchrony of Antarctic and Greenland climate change during the last glacial period. Nature 394, 739-743.

Boom, A., Marchant, R., Hooghiemstra, H., Sinnighe-Damsté, J. S., 2002. $\mathrm{CO}_{2^{-}}$ and temperature-controlled altitudinal shifts of $\mathrm{C}_{4^{-}}$and $\mathrm{C}_{3}$-dominated grasslands allow reconstruction of paleoatmospheric $p \mathrm{CO}_{2}$. Palaeogeography, Palaeoclimatology, Palaeoecology 177, 151-168.

Braconnot, P., Joussaume, S., de Noblet, N., Ramstein, G., 2000. Mid-Holocene and Last Glacial Maximum African monsoon changes as simulated within the Paleoclimate Modelling Intercomparison Project. Global and Planetary Change 26, 51-66.

Broecker, W. S., Lynch-Stieglitz, J., Clark, E., Hajdas, I., Bonani, G., 2001. What caused the atmosphere's $\mathrm{CO}_{2}$ content to rise during the last 8000 years? Geochemistry Geophysics Geosystems 2, doi: 2001GC000177.

Brook, E. J., Harder, S., Serveringhaus, J., Steig, E. J., Sucher, C. M., 2000. On the origin and timing of rapid changes in atmospheric methane during the last glacial period. Global Biogeochemical Cycles 14, 559-572.

Brook, E. J., Sowers, T., Orchardo, J., 1996. Rapid variations in atmospheric methane concentration during the past 110,000 years. Science 273, 1087-1091.

Brovkin, V., Bendtsen, J., Claussen, M., Ganopolski, A., Kubatzki, C., Petoukhov, V., Andreev, A., 2002a. Carbon cycle, vegetation, and climate dynamics in the Holocene: Experiments with the CLIMBER-2 model. Global Biogeochemical Cycles 16, 1139, doi:10.1029/2001GB001662.

Brovkin, V., Hofmann, M., Bendtsen, J., Ganopolski, A., 2002b. Ocean biology could control atmospheric $\delta^{13} \mathrm{C}$ during glacial-interglacial cycle. Geochemistry, Geophysics, Geosystems 3, 10.1029/2001GC000270.

Bruno, M., Joos, F., 1997. Terrestrial carbon storage during the past 200 years: A Monte Carlo analysis of $\mathrm{CO}_{2}$ data from ice core and atmospheric measurements. Global Biogeochemical Cycles 11, 111-124.

Claussen, M., Mysak, L. A., Weaver, A. J., Crucifix, M., Fichefet, T., Loutre, M.-F., Weber, S. L., Alcamo, J., Alexeev, V. A., Berger, A., Calov, R., Ganopolski, A., Goosse, H., Lohman, G., Lunkeit, F., Mokhov, I. I., Petoukhov, V., Stone, P., Wang, Z., 2002. Earth System Models of Intermediate Complexity: Closing the Gap in the Spectrum of Climate System Models. Climate Dynamics 18, 579-586.

Collatz, G. J., Berry, J. A., Clark, J. S., 1998. Effects of climate and atmospheric $\mathrm{CO}_{2}$ partial pressure on the global distribution of $\mathrm{C}_{4}$ grasses: present, past and future. Oecologia 114, 441-454. 
Cramer, W., Bondeau, A., Woodward, F. I., Prentice, I. C., Betts, R. A., Brovkin, V., Cox, P. M., Fisher, V., Foley, J. A., Friend, A. D., Kucharik, C., Lomas, M. R., Ramankutty, N., Sitch, S., Smith, B., White, A., Young-Molling, C., 2001. Global response of terrestrial ecosystem structure and function to $\mathrm{CO}_{2}$ and climate change: results from six dynamic global vegetation models. Global Change Biology 7, 357-375.

Crowley, T. J., 1995. Ice age terrestrial carbon changes revisited. Global Biogeochemical Cycles 9 (3), 377-389.

Crucifix, M., Loutre, M. F., 2002. Transient simulations over the last interglacial period (126-115 kyr BP): feedback and forcing analysis. Climate Dynamics 19, 417-433.

Curry, W. B., Duplessy, J. C., Labeyrie, L. D., Shackleton, N. J., 1988. Changes in the distribution of $\delta^{13} \mathrm{C}$ of deep water $\sum \mathrm{CO}_{2}$ between the last glaciation and the Holocene. Paleoceanography 3 (3), 317-341.

Dahl-Jensen, D., Mosegaard, K., Gundestrup, N., Clow, G. D., Johnsen, S. J., Hansen, A. W., Balling, N., 1998. Past temperatures directly from the Greenland ice sheet. Science 282, 268-271.

Daniel, C., 1973. One-at-a-Time Plans. Journal of the American Statistical Association $68,353-360$.

Dargaville, R. J., Heimann, M., McGuire, A. D., Prentice, I. C., C., I., Kicklighter, D. W., Joos, F., Clein, J. S., Esser, G., Foley, J., Kaplan, J., Meier, R. A., Melillo, J. M., Moore, B., Ramankutty, N., Reichenau, T., Schloss, A., Sitch, S., Tian, H., Williams, L., Wittenberg, U., 2002. Evaluation of terrestrial carbon cycle models with atmospheric $\mathrm{CO} 2$ measurements: Results from transient simulations considering increasing CO2, climate, and land-use effects. Global Biogeochemical Cycles 16, 1092, doi: 10.1029/2001GB001426.

Dean, W. E., Gorham, E., 1998. Magnitude and significance of carbon burial in lakes, reservoirs, and peatlands. Geology 26, 535-538.

Dixon, R. K., Brown, S., Houghton, R. A., Solomon, A. M., Trexler, M. C., Wisniewski, J., 1994. Carbon pools and flux of global forest ecosystems. Science 263, $185-190$.

Duplessy, J. C., Shackleton, N. J., Fairbanks, R. G., Labeyrie, L., Oppo, D., Kallel, N., 1988. Deep water source variations during the last climatic cycle and their impact on the global deepwater circulation. Paleoceanography 3, 343-360.

Emanuel, W. R., Killough, G. G., Post, W. M., Shugart, H. H., 1984. Modeling terrestrial ecosystems in the global carbon cycle with shifts in carbon storage capacity by land-use change. Ecology 65, 970-983.

Esser, G., Lautenschlager, M., 1994. Estimating the change of carbon in the terrestrial biosphere from $18000 \mathrm{BP}$ to present using a carbon cycle model. Environmental Pollution 83, 45-53.

Fairbanks, R. G., 1990. The age and origin of the Yonger Dryas climate event in Greenland ice cores. Paleoceanography 5, 937-948.

Falloon, P., Smith, P., Coleman, K., Marshall, S., 1998. Estimating the size of the inert organic matter pool from total soil organic carbon content for use in the rothamsted carbon model. Soil Biology and Biochemistry 30, 1207-1211.

FAO, 2001. State of the world's forests 2001. FAO, Rom.

Farrera, I., Harrison, S. P., Prentice, I. C., Ramstein, G., Guiot, J., Bartlein, 
P. J., Bonnefille, R., Bush, M., Cramer, W., von Grafenstein, U., Holmgren, K., Hooghiemstra, H., Hope, G., Jolly, D., Lauritzen, S.-E., Ono, Y., Pinot, S., Stute, M., Yu, G., 1999. Tropical climates at the Last Glacial Maximum: a new synthesis of terrestrial palaeoclimate data. I. Vegetation, lake-levels and geochemistry. Climate Dynamics 15, 823-856.

Fischer, H., Wahlen, M., Smith, J., 2003. Reconstruction of glacial/interglacial changes in the global carbon cycle from $\mathrm{CO}_{2}$ and $\delta^{13} \mathrm{CO}_{2}$ in Antarctic ice cores. Memoirs of the National Institute for Polar Research, Special Issue 57, 121-138.

Foley, J. A., 1994. The sensitivity of the terrestrial biosphere to climate change: a simulation of the middle Holocene. Global Biogeochemical Cycles 8, 505-525.

François, L. M., Delire, C., Warnant, P., Munhoven, G., 1998. Modelling the glacialinterglacial changes in the continental biosphere. Global and Planetary Change $16-17,37-52$.

François, L. M., Godderis, Y., Warnant, P., Ramstein, G., de Noblet, N., Lorenz, S., 1999. Carbon stocks and isotopic budgets of the terrestrial biosphere at midHolocene and last glacial maximum times. Chemical Geology 159, 163-189.

Freeman, C., Evans, C. D., Monteith, D. T., Reynolds, B., Fenner, N., 2001. Export of organic carbon from peat soils. Nature 412, 785.

Friedlingstein, P., Fung, I., Holland, E., John, J., Brasseur, G., Erickson, D., Schimel, D., 1995a. On the contribution of $\mathrm{CO}_{2}$ fertilization to the missing biospheric sink. Global Biogeochemical Cycles 9, 541-556.

Friedlingstein, P., Prentice, K. C., Fung, I. Y., John, J. G., Brasseur, G. P., 1995b. Carbon-biosphere-climate interactions in the last glacial maximum climate. Journal of Geophysical Research 100 (D4), 7203-7221.

Ganopolski, A., Rahmstorf, S., Petoukhov, V., Claussen, M., 1998. Simulation of modern and glacial climates with a coupled global model of intermediate complexity. Nature 391, 351-356.

Gerber, S., Joos, F., Brügger, P., Stocker, T. F., Mann, M. E., Sitch, S., Scholze, M., 2003. Constraining temperature variations over the last millennium by comparing simulated and observed atmospheric $\mathrm{CO}_{2}$. Climate Dynamics 20, 281-299.

Gill, R. A., Polley, H. W., Johnson, H. B., Anderson, L. J., Maherall, H., Jackson, R. B., 2002. Nonlinear grassland responses to past and future atmospheric $\mathrm{CO}_{2}$. Nature 417, 279-282.

Gorham, E., 1991. Northern peatlands: role in the carbon cycle and probable responses to climatic warming. Ecological Applications 1, 182-195.

Grace, J., 1991. Vegetation and climate: a tenuous link. In: Esser, G., Overdieck, D. (Eds.), Modern ecology: basic and applied aspects. Elsevier, Amsterdam, The Netherlands, pp. 711-722.

Grootes, P. M., Stuiver, M., 1997. Oxygen 18/16 variability in Greenland snow and ice with $10^{3}$ to $10^{5}$-year time resolution. Journal of Geophysical Research 102, 26455-26470.

Gupta, A. K., Anderson, D. M., Overpeck, J. T., 2003. Abrupt changes in the Asian southwest monsoon during the Holocene and their links to the North Atlantic Ocean. Nature 421, 354-357.

Hall, D. O., Scurlock, J. M. O., 1991. Tropical grasslands and their role in the global carbon cycle. In: Esser, G., Overdieck, D. (Eds.), Modern ecology: basic and applied aspects. Elsevier, Amsterdam, The Netherlands, pp. 659-677. 
Harvey, L. D. D., 1989. Effect of model structure on the response of terrestrial biosphere models to $\mathrm{CO}_{2}$ and temperature increase. Global Biogeochemical Cycles $3,137-153$.

Hedges, J. I., Keil, R. G., Benner, R., 1997. What happens to terrestrial organic matter in the ocean? Organic Geochemistry 27, 195-212.

Heimann, M., Esser, G., Haxeltine, A., Kaduk, J., Kicklighter, D. W., Knorr, W., Kohlmeier, G. H., McGuire, A. D., Melillo, J., Moore-III, B., otto, R. D., Prentice, I. C., Sauf, W., Schloss, A., Sitch, S., Wittenberg, U., Würth, G., 1998. Evaluation of terrestrial carbon cycle models through simulations of the seasonal cycle of atmospheric $\mathrm{CO}_{2}$ : First results of a model intercomparison study. Global Biogeochemical Cycles 12, 1-24.

Houghton, J. T., Ding, Y., Griggs, D. J., Noguer, M., van der Linden, P. J., Dai, X., Maskell, K., Johnson, C. A. (Eds.), 2001. Climate Change 2001: The Scientific Basis. Contribution of Working Group I to the Third Assessment Report of the Intergovernmental Panel on Climate Change. Cambridge University Press, Cambridge, U.K.

Huang, Y., Street-Perrott, F. A., Metcalfe, S. E., Brenner, M., Moreland, M., Freeman, K. H., 2001. Climate change as the dominant control on glacial-interglacial variations in $\mathrm{C}_{3}$ and $\mathrm{C}_{4}$ plant abundance. Science 293, 1647-1651.

Indermühle, A., Monnin, E., Stauffer, B., Stocker, T. F., 2000. Atmospheric $\mathrm{CO}_{2}$ concentration from 60 to $20 \mathrm{kyr}$ BP from the Taylor Dome ice core, Antarctica. Geophysical Research Letters 27, 735-738.

Indermühle, A., Stocker, T. F., Joos, F., Fischer, H., Smith, H. J., Wahlen, M., Deck, B., Mastroianni, D., Tschumi, J., Blunier, T., Meyer, R., Stauffer, B., 1999. Holocene carbon-cycle dynamics based on $\mathrm{CO}_{2}$ trapped in ice at Taylor dome, Antarctica. Nature 398, 121-126.

Jackson, R. B., Banner, J. L., Jobbagy, E. G., Pockman, W. T., Wall, D. H., 2002. Ecosystem carbon loss with woody plant invasion of grasslands. Nature $418,623-$ 626.

Jolly, D., Haxeltine, A., 1997. Effect of low glacial atmospheric $\mathrm{CO}_{2}$ on tropical African montane vegetation. Science 276, 786-788.

Jones, I. W., Munhoven, G., Tranter, M., Huybrechts, P., Sharp, M. J., 2002. Modelled glacial and non-glacial $\mathrm{HCO}_{3}^{-}$, Si and Ge fluxes since the LGM: little potential for impact on atmospheric $\mathrm{CO}_{2}$ concentrations and a potential proxy of continental chemical erosion, the marine Ge/Si ratio. Global and Planetary Change 33, 139-153.

Joos, F., Bruno, M., 1998. Long-term variability of the terrestrial and oceanic carbon sinks and the budgets of the carbon isotopes ${ }^{13} \mathrm{C}$ and ${ }^{14} \mathrm{C}$. Global Biogeochemical Cycles 12, 277-295.

Joos, F., Bruno, M., Fink, R., Siegenthaler, U., Stocker, T. F., 1996. An efficient and accurate representation of complex oceanic and biospheric models of anthropogenic carbon uptake. Tellus 48B (3), 397-417.

Joos, F., Meyer, R., Bruno, M., Leuenberger, M., 1999a. The variability in the carbon sinks as reconstructed for the last 1000 years. Geophysical Research Letters 26, 1437-1440.

Joos, F., Plattner, G.-K., Stocker, T. F., Marchal, O., Schmittner, A., 1999b. Global warming and marine carbon cycle feedbacks on future atmospheric $\mathrm{CO}_{2}$. Science 
$284,464-467$.

Joussaume, S., Taylor, K. E., Braconnot, P., Mitchell, J. F. B., Kutzbach, J. E., Harrison, S. P., Prentice, I. C., Broccoli, A. J., Abe-Ouchi, A., Bartlein, P. J., Bonfils, C., Dong, B., Guiot, J., Herterich, K., Hewitt, C. D., Jolly, D., Kim, J. W., Kislov, A., Kitoh, A., Loutre, M. F., Masson, V., McAvaney, B., McFarlane, N., de Noblet, N., Peltier, W. R., Peterschmitt, J. Y., Pollard, D., Rind, D., Royer, J. F., Schlesinger, M. E., Syktus, J., Thompson, S., Valdes, P., Vettoretti, G., Webb, R. S., Wyputta, U., 1999. Monsoon changes for 6000 years ago: Results of 18 simulations from the Paleoclimate Modeling Intercomparison Project (PMIP). Geophysical Research Letters 26, 859-862.

Jouzel, J., Lorius, C., Petit, J. R., Genthon, C., Barkov, N. I., Kotlyakov, V. M., Petrov, V. M., 1987. Vostok ice core: a continuous isotope temperature record over the last climate cycle (160,000 years). Nature 329, 403-408.

Kageyama, M., Peyron, O., Pinot, S., Tarasov, P., Guiot, J., Jousaume, S., Ramstein, G., 2001. The Last Glacial Maximum climate over Europe and western Siberia: a PMIP comparsion between models and data. Climate Dynamics 17, 23-43.

Kaplan, J. O., Prentice, I. C., Knorr, W., Valdes, P. J., 2002. Modeling the dynamics of terrestrial carbon storage since the Last Glaical Maximum. Geophysical Research Letters 29, 2074, doi: 10.1029/2002GL015230.

Keeling, C. D., Chin, J. F. S., Whorf, T. P., 1996. Increased activity of northern vegetation inferred from atmospheric $\mathrm{CO}_{2}$ measurements. Nature 382, 146-149.

Kheshgi, H. S., Jain, A. K., Wuebbles, D. J., 1996. Accounting for the missing carbon-sink with the $\mathrm{CO}_{2}$-fertilization effect. Climatic Change 33, 31-62.

Kicklighter, D. W., Bruno, M., Dönges, S., Esser, G., Heimann, M., Helfrich, J., Ift, F., Joos, F., Kaduk, J., Kohlmeier, G. H., McGuire, A. D., Melillo, J. M., Meyer, R., Moore-III, B., Nadler, A., Prentice, I. C., Sauf, W., Schloss, A. L., Sitch, S., Wittenberg, U., Würth, G., 1999. A first-order analysis of the potential rôle of the $\mathrm{CO}_{2}$ fertilization to affect the global carbon budget: a comparison of four terrestrial biosphere models. Tellus 51B, 343-366.

Kim, S.-J., Flato, G. M., Boer, G. J., McFarlane, N. A., 2002. A coupled climate model simulation of the Last Glacial Maximum, Part 1: transient multi-decadal response. Climate Dynamics 19, 515-537.

Körner, C., 2000. Biosphere responses to $\mathrm{CO}_{2}$ enrichment. Ecological Applications 10, 1590-1619.

Kutzbach, J., Gallimore, R., Harrison, S., Behling, P., Selin, R., Laarif, F., 1998. Climate and biome simulations for the past 21,000 years. Quaternary Science Reviews 17, 473-506.

LeGrand, P., Alverson, K., 2001. Variations in atmospheric $\mathrm{CO}_{2}$ during glacial cycles from an inverse ocean modelling perspective. Paleoceanography 16, 604-616.

Lloyd, J., Farquhar, G. D., $1994 .{ }^{13} \mathrm{C}$ discrimination during $\mathrm{CO}_{2}$ assimilation by the terrestrial biosphere. Oecologia 99, 201-215.

Marchal, O., Stocker, T. F., Joos, F., 1998. A latitude-depth, circulationbiogeochemical ocean model for paleoclimate studies. Development and sensitivities. Tellus 50B, 290-316.

Marchal, O., Stocker, T. F., Joos, F., Indermühle, A., Blunier, T., Tschumi, J., 1999. Modelling the concentration of atmospheric $\mathrm{CO}_{2}$ during the Younger Dryas 
climate event. Climate Dynamics 15, 341-354.

McGuire, A. D., Sitch, S., Dargaville, R., Esser, G., Foley, J., Heimann, M., Joos, F., Kaplan, J., Kicklighter, D. W., Meier, R. A., Melillo, J. M., Moore, B., Prentice, I. C., Ramankutty, N., Reichenau, T., Schloss, A., Tian, H., Wittenberg, U., 2001. The effects of $\mathrm{CO}_{2}$, climate and land-use on terrestrial carbon balance, 1920-1992: an analysis with four process-based ecosystem models. Global Biogeochemical Cycles 15, 183-206.

Meese, D. A., Alley, R., Fiacco, R., Germani, M., Gow, A., Grootes, P., Illing, M., Mayewski, P., Morrison, M., Ram, M., Taylor, K., Yang, Q., Zielinski, G., 1994. Preliminary depth-age scale of the GISP2 ice core. Special CRREL Report 94-1, US.

Meese, D. A., Gow, A., Alley, R., Zielinski, G., Grootes, P., Ram, M., Taylor, K., Mayewski, P., Bolzan, J., 1997. The Greenland Ice Sheet Project 2 depth-age scale: Methods and results. Journal of Geophysical Research 102, 26411-26423.

Michel, E., Labeyrie, L. D., Duplessy, J.-C., Gorfti, N., Labracherie, M., Turon, J.L., 1995. Could deep Subantarctic convection feed the world deep basins during the last glacial maximum? Paleoceanography 10, 927-942.

Myneni, R. B., Keeling, C. D., Tucker, C. J., Asrar, G., Nemani, R. R., 1997. Increased plant growth in the northern high latitudes from 1981 to 1991. Nature 386, 698-702.

Otto, D., Rasse, D., Kaplan, J., Warnant, P., François, L., 2002. Biospheric carbon stocks reconstructed at the last glacial maximum: comparison between general circulation models using prescribed and computed sea surface temperature. Global and Planetary Change 33, 117-138.

Peng, C. H., Guiot, J., van Campo, E., 1995. Reconsturction of past terrestrial carbon storage in the Northern Hemisphere from the Osnabrück Biosphere Model and paleodata. Climate Research 5, 107-118.

Petit, J. R., Jouzel, J., Raynaud, D., Barkov, N. I., Barnola, J.-M., Basile, I., Bender, M., Chappellaz, J., Davis, M., Delaygue, G., Delmotte, M., Kotlyakov, V. M., Legrand, M., Lipenkov, V. Y., Lorius, C., Pépin, L., Ritz, C., Saltzman, E., Stievenard, M., 1999. Climate and atmospheric history of the past 420,000 years from the Vostok ice core, Antarctica. Nature 399, 429-436.

Pinot, S., Ramstein, G., Harrison, S. P., Prentice, I. C., Guiot, J., Stute, M., Joussaume, S., 1999. Tropical paleoclimate at the Last Glacial Maximum: comparison of Paleoclimate Modeling Intercomparison Project (PMIP) simulations and paleodata. Climate Dynamics 15, 857-874.

Prentice, I. C., Farquhar, G. D., Fasham, M. J. R., Goulden, M. L., Heimann, M., Jaramillo, V. J., Kheshgi, H. S., Quéré, C. L., Scholes, R. J., Wallace, D. W. R., 2001. The carbon cycle and atmospheric carbon dioxide. In: Houghton, J. T., Ding, Y., Griggs, D. J., Noguer, M., van der Linden, P. J., Dai, X., Maskell, K., Johnson, C. A. (Eds.), Climate Change 2001: The Scientific Basis. Contribution of Working Group I to the Third Assessment Report of the Intergovernmental Panel on Climate Change. Cambridge University Press, Cambridge, U.K., pp. 183-237.

Prentice, I. C., Sykes, M. T., Lautenschlager, M., Harrison, S. P., Denissenko, O., Bartlein, P. J., 1993. Modelling global vegetation patterns and terrestrial carbon storage at the last glacial maximum. Global Ecology and Biogeography Letters 
$3,67-76$.

Prentice, K. C., Fung, I. Y., 1990. The sensitivity of terrestrial carbon storage to climate change. Nature 346, 48-51.

Raich, J. W., Schlesinger, W. H., 1992. The global carbon dioxide flux in soil respiration and its relationship to vegetation and climate. Tellus 44B, 81-99.

Randerson, J. T., Still, C. J., Ballé, J. J., Fung, I. Y., Doney, S. C., Tans, P. P., Conway, T. J., White, J. W. C., Vaughn, B., Suits, N., Denning, A. S., 2002. Carbon isotope discrimination of artic and boreal biomass inferred from remote atmospheric measurements and a biosphere-atmosphere model. Global Biogeochemical Cycles 16, 10.1029/2001GB001435.

Raymond, P. A., Bauer, J. E., 2001. Riverine export of aged terrestrial organic matter to the North Atlantic Ocean. Nature 409, 497-500.

Ruimy, A., Saugier, B., Dedieu, G., 1994. Methodology for the estimation of terrestrial net primary production from remotely sensed data. Journal of Geophysical Research 99 (D3), 5263-5283.

Schimel, D. S., Braswell, B. H., Holland, E. A., McKeown, R., Ojima, D. S., Painter, T. H., Parton, W. J., Townsend, A. R., 1994. Climatic, edaphic and biotic controls over storage and turnover of carbon in soils. Global Biogeochemical Cycles 8, 279293.

Schlesinger, W. H., Lichter, J., 2001. Limited carbon storage in soil and litter of experimental forest plots under increased atmospheric $\mathrm{CO}_{2}$. Nature 411, 466-469.

Schulz, H., von Rad, U., Erlenkeuser, H., 1998. Correlation between Arabian Sea and Greenland climate oscillations of the past 110,000 years. Nature 393, 54-57.

Shaw, M. R., Zavaleta, E. S., Chiariello, N. R., Cleland, E. E., Mooney, H. A., Field, C. B., 2002. Grassland responses top global environmental changes suppressed by elevated $\mathrm{CO}_{2}$. Science 298, 1987-1990.

Siegenthaler, U., Oeschger, H., 1987. Biospheric $\mathrm{CO}_{2}$ emissions during the past 200 years reconstructed by deconvolution of ice core data. Tellus 39B, 140-154.

Sigman, D. M., McCorkle, D. C., Martin, W. R., 1998. The calcite lysocline as a constraint on glacial/interglacial low-latitude production changes. Global Biogeochemical Cycles 12 (3), 409-427.

Smith, H. J., Fischer, H., Wahlen, M., Mastroianni, D., Deck, B., 1999. Dual modes of the carbon cycle since the Last Glacial Maximum. Nature 400, 248-250.

Spero, H. J., Lea, D. W., 2002. The cause of carbon isotope minimum events on glacial terminations. Science 296, 522-525.

Street-Perrott, F. A., Huang, Y., Perrott, R. A., Eglington, G., Barker, P., Khelifa, L. B., Harkness, D. D., Olago, D. O., 1997. Impact of lower atmospheric carbon dioxide on tropical mountain ecosystems. Science 278, 1422-1426.

TEMPO, 1996. Potential role of vegetation feedback in the climate sensitivity of high-latitude regions: a case study at 6000 years BP. Global Biogeochemical Cycles 10, 727-736.

Texier, D., de Noblet, N., Harrison, S. P., Haxeltine, A., Jolly, D., Joussaume, S., Laarif, F., Prentice, I. C., Tarasov, P., 1997. Quantifying the role of biosphereatmosphere feedbacks in climate change: coupled model simulations for 6000 years $\mathrm{BP}$ and comparison with palaeodata for northern Eurasia and northern Africa. Climate Dynamics 13, 865-882.

Toggweiler, J. R., 1999. Variation of atmospheric $\mathrm{CO}_{2}$ by ventilation of the ocean's 
deepest water. Paleoceanography 14 (5), 571-588.

Trudinger, C. M., Enting, I. G., Francey, R. J., Etheridge, D. M., Rayner, P. J., 1999. Long-term variability in the global carbon cycle inferred from a high-precision $\mathrm{CO}_{2}$ and $\delta^{13} \mathrm{C}$ ice-core record. Tellus 51B, 233-248.

Valentini, R., Matteucci, G., Dolman, A. J., Schulze, E.-D., Rebmann, C., Moors, E. J., Granier, A., Gross, P., Jensen, N. O., Pilegaard, K., Lindroth, A., Grelle, A., Bernhofer, C., Grünwald, T., Aubinet, M., Ceulemans, R., Kowalski, A. S., Vesala, T., Rannik, Ü., Berbigier, P., Loustau, D., Gudmundsson, J., Thorgeirsson, H., Ibrom, A., Morgenstern, K., Clement, R., Moncrieff, J., Montagnani, L., Minerbi, S., Jarvis, P. G., 2000. Respiration as the main determinant of carbon balance in European forests. Nature 404, 861-865.

Van't-Hoff, J. H., 1898. Lectures on theoretical and physical chemistry. Part I. Chemical dynamics (translated by R. A. Lehfeldt). Edward Arnold, London.

Vogel, J. C., 1993. Variability of carbon isotope fractionation during photosynthesis. In: Ehleringer, J. R., Hall, A. E., Farquhar, G. D. (Eds.), Stable isotopes and plant carbon-water relations. Academic Press, San Diego, USA, pp. 29-46.

Walker, B., Steffen, W., 1996. Global change and terrestrial ecosystems. Vol. 2 of International Geosphere-Biosphere Programme Book Series. Cambridge University Press, Cambridge, U.K.

Walker, B., Steffen, W., Canadell, J., Ingram, J., 1999. The terrestrial biosphere and global change. Vol. 5 of International Geosphere-Biosphere Programme Book Series. Cambridge University Press, Cambridge, U.K.

Wang, Y. J., Cheng, H., Edwards, R. L., An, Z. S., Wu, J. Y., Shen, C.-C., Dorale, J. A., 2001. A high-resolution absolute-dated late Pleistocene monsoon record from Hulu cave, China. Science 294, 2345-2348.

Whitlock, C., Bartlein, P. J., 1997. Vegetation and climate change in northwest America during the past $125 \mathrm{kyr}$. Nature 388, 57-61.

Wiegand, T., Jeltsch, F., Hanski, I., Grimm, V., 2003a. Using pattern-oriented modeling for revealing hidden information: a key for reconciling ecological theory and application. Oikos 100, 209-222.

Wiegand, T., Revilla, E., Knauer, F., 2003b. Reducing uncertainty in spatially explicit population models. Biodiversity and Conservation, in press.

Wösten, J. H. M., Ismail, A. B., van Wijk, A. L. M., 1997. Peat subsidence and its practical implications: a case study in Malaysia. Geoderma 78, 25-36.

\section{Figure captions}

Fig. 1: Structure of the model. C4: $\mathrm{C}_{4}$ ground vegetation; $\mathrm{C} 3$ : $\mathrm{C}_{3}$ ground vegetation; NW: non-woody parts of trees; W: woody parts of trees; D: detritus or above-ground litter; FS: fast decomposing soil or below-ground litter; SS: slow decomposing soil. Atmospheric $p \mathrm{CO}_{2}$ concentrations are prescribed from ice core data. Arrows indicate the fluxes of carbon.

Fig. 2: Latitudinal distribution of land area for preindustrial times. Data are aggregated to $10^{\circ}$ bands from the $1^{\circ} \times 1^{\circ}$ resolved global elevation data set ds750.1 of 
the Scripps Institute of Oceanography (http://dss.ucar.edu/datasets/ds750.1).

Fig. 3: Time dependent driving forces of the model. A: Sea Level changes derived from coral reef terraces (Fairbanks, 1990). B: Land area $A_{\text {LAND }}$ and area covered by land ice and lakes $A_{\mathrm{ICE}}$ calculated from a linear correlation of sea level and data for the LGM and preindustrial times (Adams and Faure, 1998). C: Effective area available for terrestrial vegetation $A_{\mathrm{EFF}}=A_{\mathrm{LAND}}-A_{\mathrm{ICE}}$. D: Atmospheric $p \mathrm{CO}_{2}$ concentration and $\delta^{13} \mathrm{CO}_{2}$ measured in the Taylor Dome (o: Smith et al. (1999), $\times$ : Indermühle et al. (2000)). Taylor Dome data are plotted on the GISP2 age scale. E: Changes in atmospheric temperature. Greenland: $\delta^{18} \mathrm{O}$ of the GISP2 ice core plotted on the GISP2 time scale (Grootes and Stuiver, 1997). Antarctica: $\delta$ D of the Vostok ice core (Jouzel et al., 1987; Petit et al., 1999) plotted on GISP2 age scale (10-30 kyr BP) and GT4 age scale (0-10 kyr BP).

Fig. 4: Climatic conditions (temperature and $p \mathrm{CO}_{2}$ ) defining the preference of $\mathrm{C}_{3}$ or $\mathrm{C}_{4}$ grasses (Collatz et al., 1998; Boom et al., 2002). $T_{50}$ marks the cross-over temperature. Carbon dioxide partial pressures typically for glacial (LGM) and interglacial (IG) times are sketched with vertical lines.

Fig. 5: Sensitivity analysis of the model. Twenty-two parameters are varied six to nine times in equidistant steps around their standard values found in Table 2. The ranges of the parameter variations are given at the right border. The sensitivity of the steady state responses of 17 result variables (carbon content and $\delta^{13} \mathrm{C}$ signature in all boxes, total terrestrial carbon, average terrestrial $\delta^{13} \mathrm{C}$ and NPP) as a function of changing parameter is shown. We take the coefficient of variance $C V$ as sensitivity indicator. Legend: white: $C V<1 \%$, grey: $1 \% \leq C V<10 \%$, black: $C V \geq 10 \%$.

Fig. 6: Model spin-up for the interglacial steady state scenario IG-SS. C4 or C3: $\mathrm{C}_{4}$ or $\mathrm{C}_{3}$ ground vegetation; $\mathrm{NW}$ or $\mathrm{W}$ : non-woody or woody parts of trees; $\mathrm{D}$ : detritus, FS or SS: fast or slow decomposing soil.

Fig. 7: Simulated total carbon (in $\mathrm{PgC}$ ) bound in the terrestrial biosphere at the LGM (20 kyr BP) as a function of the parameters which determine (A) $p \mathrm{CO}_{2}$ fertilisation $(\beta),(\mathrm{B})$ succession of grassland/forest $\left(a_{\mathrm{G} / \mathrm{F}}\right),(\mathrm{C})$ temperature induced changes $\left(Q_{10}^{\mathrm{C} 3}, Q_{10}^{\mathrm{RES}}, Q_{10}^{\mathrm{C} 4}\right.$ was fixed at 1.2). Further, carbon bound in trees and the fraction of $\mathrm{C}_{4}$ material are shown in sub-figure $\mathrm{B}$, where the dependency of the latter on the $\mathrm{C}_{3} / \mathrm{C}_{4}$ succession amplitude $\left(a_{\mathrm{C} 3 / \mathrm{C} 4}\right)$ is also shown. The circles mark the preindustrial values.

Fig. 8: Simulation results of terrestrial carbon at the LGM (mean \pm 1 standard deviation) for different scenarios and different targets/filters as documented in Table 4. The grey area covers the range of our literature survey of previous estimates. Relative errors in terms of coefficence of variance (SD/mean) are plotted by bars.

Fig. 9: Sensitivity of the model to climate change of different intensity. The impact of different climate amplitudes in $p \mathrm{CO}_{2}(\mathrm{~A}, \mathrm{~B})$, temperature $(\mathrm{C}, \mathrm{D})$, and sea level $(\mathrm{E})$ on total biospheric carbon is tested in steady state simulations. In the experiments the two climate variables not varied on the $\mathrm{x}$-axes are held constant 
at their preindustrial values. $\mathrm{A}, \mathrm{C}$ (case I): moderate $p \mathrm{CO}_{2}$ forcing $(\beta=0.1) . \mathrm{B}$, $\mathrm{D}$ (case II): low $p \mathrm{CO}_{2}$ forcing $(\beta<0.1)$. Results over various acceptable parameter combinations are averaged $( \pm 1 \mathrm{SD})$.

Fig. 10: Transient modelling results of the simulated total biospheric carbon. Forcings $\left(p \mathrm{CO}_{2} ; \Delta \mathrm{T}\right.$ north and south; sea level) are normalised. A: Case I with enhanced $p \mathrm{CO}_{2}$ fertilisation. B: Case II with enhanced temperature dependence. Average (thick black line) and 1 SD (grey area) of $n=14$ or 12 simulations are shown.

Fig. 11: Cumulative carbon fluxes from atmosphere/biosphere to the ocean (A: total carbon. B: isotopic $\delta^{13} \mathrm{C}$ signal). Simulations of case I (enhanced $p \mathrm{CO}_{2}$ fertilisation) and case II (enhanced temperature dependence) compared with Taylor Dome ice core data. 
Table 1

Review of terrestrial carbon stocks at preindustrial times (PRE) and during last glacial maximum (LGM). Total terrestrial carbon (C tot), carbon of living vegetation ( $\mathrm{C}$ veg) and of litter and soils ( $\mathrm{C}$ soil) is summarized. Changes account for the differences in total carbon $(\Delta(\mathrm{C}$ tot $)=\mathrm{C}$ tot $(\mathrm{PRE})-\mathrm{C} \operatorname{tot}(\mathrm{LGM}))$. Besides the most realistic ranges in the carbon stocks boundary conditions on NPP, and on

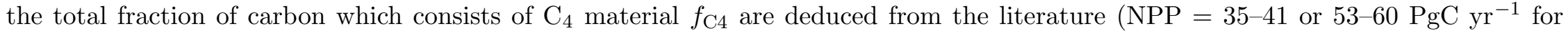
LGM or PRE, respectively; $f_{\mathrm{C} 4}=30-33 \%$ or 19-21\% for LGM or PRE, respectively) (Lloyd and Farquhar, 1994; Ruimy et al., 1994; François et al., 1998, 1999; Cramer et al., 2001). NPP and $f_{\mathrm{C} 4}$ for the LGM are based on modelling studies only and, thus, represent only weak indicators which were only used for uncertainty estimates.

\begin{tabular}{|c|c|c|c|c|c|c|c|c|}
\hline \multirow[b]{2}{*}{ Reference } & \multirow[b]{2}{*}{ Source } & \multicolumn{3}{|c|}{ Preindustrial times } & \multicolumn{3}{|c|}{ Last Glacial Maximum } & \multirow{2}{*}{$\begin{array}{c}\text { Change } \\
\Delta(\mathrm{C} \text { tot }) \\
(\mathrm{PgC})\end{array}$} \\
\hline & & $\begin{array}{l}\text { C veg } \\
(\mathrm{PgC})\end{array}$ & $\begin{array}{l}\text { C soil } \\
(\mathrm{PgC})\end{array}$ & $\begin{array}{l}\text { C tot } \\
(\mathrm{PgC})\end{array}$ & $\begin{array}{l}\text { C veg } \\
(\mathrm{PgC})\end{array}$ & $\begin{array}{l}\text { C soil } \\
(\mathrm{PgC})\end{array}$ & $\begin{array}{l}\mathrm{C} \text { tot } \\
(\mathrm{PgC})\end{array}$ & \\
\hline Kaplan et al. (2002) & model & & & 2455 & & & 1634 & 821 \\
\hline François et al. (1999) & model & $646-650$ & $1334-1379$ & $1984-2025$ & & & $1250-1500$ & $441-710$ \\
\hline François et al. (1998) & model & 622 & 1322 & 1943 & 391 & 947 & 1337 & $134-606$ \\
\hline Adams and Faure (1998) & database $^{a}$ & 904 & 1700 & 2604 & 352 & 610 & 962 & $900-1900$ \\
\hline Crowley (1995) & database & & & $2167-2422$ & & & $1378-1522$ & $750-1050$ \\
\hline Friedlingstein et al. (1995b) & model & 844 & 1288 & 2132 & $640-1111$ & $980-1610$ & $1720-2720$ & $507-717$ \\
\hline Esser and Lautenschlager (1994) & model & 708 & 1698 & 2406 & $470-617$ & $1405-1820$ & $1870-2437$ & $-31-536$ \\
\hline Bird et al. (1994) & $\mathrm{C}, \delta^{13} \mathrm{C}^{\mathrm{b}}$ & & & & & & & $270-720$ \\
\hline Prentice et al. (1993) & model & $470-1090$ & $1097-1578$ & $1566-2668$ & $391-921$ & $974-1334$ & $1365-2254$ & $300-700$ \\
\hline Range & & $646-1090$ & $1097-1700$ & $1566-2668$ & $352-1111$ & 417-1820 & $805-2720$ & $-31-1900$ \\
\hline
\end{tabular}

a They give an error range of $\pm 30 \%$. The buildup of carbon in peat plays an important role here.

${ }^{\mathrm{b}}$ Estimates based on mass balances of known changes in the marine and atmospheric carbon and $\delta^{13} \mathrm{C}$ records.

${ }^{\mathrm{c}}$ Most realistic ranges are achieved by a reduction on the most recent results of various working groups and by omitting

the most extreme and probably unrealistic results which lead to range for $\mathrm{C}$ tot of $-31 \mathrm{PgC}$ and $1900 \mathrm{PgC}$. 
Table 2

Parameters of the model.

\begin{tabular}{lllll}
\hline Symbol & Value & Unit & Comment $^{\mathrm{a}}$ & Sources $^{\mathrm{b}^{\mathrm{b}}}$ \\
\hline \multicolumn{2}{l}{ Basic parameters } & & & \\
$\tau$ & $4,4,2,25,5,100,1000$ & $\mathrm{yr}$ & Turnover times of the C4 C3 NW W D FS SS boxes & {$[1,2]$} \\
$t^{\mathrm{R}}$ & $4,4,15$ & $\mathrm{yr}$ & Recovery times of photosynthetic boxes (C4 C3 NW) & \\
$C^{*}$ & $34,27,40$ & $\mathrm{PgC}$ & Interglacial steady states of the C4 C3 NW boxes & {$[2]$} \\
$\theta$ & $33,33,0,11.775$, & $\%$ & Soil-forming fraction of C4 C3 NW W & \\
$\vartheta$ & $93.75,98.5,100$ & $\%$ & Fraction of respiration in outgoing fluxes of D FS SS & {$[3]$} \\
$r_{\mathrm{NPP}}$ & 0.88 & - & Ratio of NW/W photosynthetic influx & \\
$\epsilon_{C 3}$ & -19 & $\%$ & Fractionation factor for C3 photosynthesis & {$[4,5]$} \\
$\epsilon_{C 4}$ & -5 & $\%$ & Fractionation factor for C 4 photosynthesis & {$[4,5]$}
\end{tabular}

Control parameters of forcings

\begin{tabular}{ll}
$\beta$ & $0.0-0.4$ \\
$Q_{10}^{\mathrm{C} 4}$ & $1.0-2.0$ \\
$Q_{10}^{\mathrm{C} 3}$ & $1.0-2.0$ \\
$Q_{10}^{\mathrm{RES}}$ & $1.0-2.0$ \\
$a_{\mathrm{C} 3 / \mathrm{C} 4}$ & $0.0-0.1$ \\
$a_{\mathrm{G} / \mathrm{F}}$ & $0.0-0.05$ \\
\hline
\end{tabular}

Factor controlling $p \mathrm{CO}_{2}$ fertilization effect on NPP

$Q_{10}$ factor for temperature dependent NPP of $\mathrm{C}_{4}$ plants

$Q_{10}$ factor for temperature dependent NPP of $\mathrm{C}_{3}$ plants

$Q_{10}$ factor for temperature dependent respiration

Amplitude of succession from $\mathrm{C} 3$ to $\mathrm{C} 4=f\left(p \mathrm{CO}_{2}, T\right)$

${ }^{a} \mathrm{C} 4$ or $\mathrm{C} 3$ : $\mathrm{C}_{4}$ or $\mathrm{C}_{3}$ ground vegetation; $\mathrm{NW}$ or $\mathrm{N}$ : non-woody or woody parts of trees; D: detritus, FS or SS: fast or slow decomposing soil.

b References others than Emanuel et al. (1984): [1]: Schimel et al. (1994). [2]: François et al. (1998). [3]: Houghton et al. (2001). [4]: Vogel (1993). [5]: Lloyd and Farquhar (1994). [6]: Harvey (1989). [7]: Kicklighter et al. (1999). [8]: Kheshgi et al. (1996). 
Table 3

Parameters used to calculate the cross-over temperature $T_{50}$ (taken from Collatz et al., 1998).

\begin{tabular}{llll}
\hline & Value & Unit & Comment \\
\hline$\alpha_{C 3}$ & 0.085 & $\mathrm{~mol} / \mathrm{mol}$ & Intrinsic quantum efficiency of $\mathrm{C}_{3} \mathrm{NPP}$ \\
$\alpha_{C 4}$ & 0.06 & $\mathrm{~mol} / \mathrm{mol}$ & Intrinsic quantum efficiency of $\mathrm{C}_{4} \mathrm{NPP}$ \\
$s_{25}$ & 2600 & - & Specificity of Rubisco \\
$Q_{10}$ & 0.57 & - & Temperature dependent change in $\mathrm{s}$ \\
$p \mathrm{O}_{2}$ & 21000 & $\mathrm{~Pa}$ & Atmospheric $\mathrm{O}_{2}$ partial pressure \\
\hline
\end{tabular}

a Specificity of Rubisco for $\mathrm{CO}_{2}$ relative to $\mathrm{O}_{2}$ at $25^{\circ} \mathrm{C}$. 
Table 4

Simulation results. Target ranges are deduced from the literature review. All simulations apart from those labelled "transient" are run in a steady state mode for 10,000 years starting with all terrestrial stocks at $\mathrm{C}=0.1 \mathrm{PgC}, \delta^{13} \mathrm{C}=0 \%$ forced by climate conditions derived from our archives for $t=0 \mathrm{kyr} \mathrm{BP}$ (PRE), and $t=20 \mathrm{kyr} \mathrm{BP}$ (LGM), respectively. The criteria NPP and $f_{\mathrm{C} 4}$ for the LGM are based on modelling studies only and thus represent only weak indicators.

\begin{tabular}{|c|c|c|c|c|c|c|c|c|c|c|c|}
\hline \multirow[t]{2}{*}{ Scenario } & \multirow[t]{2}{*}{$n$} & \multicolumn{2}{|c|}{ Vegetation $^{\mathrm{a}}(\mathrm{PgC})$} & \multicolumn{2}{|c|}{ Soil $^{b}(\mathrm{PgC})$} & \multicolumn{2}{|c|}{ Total C (PgC) } & \multicolumn{2}{|c|}{$f_{\mathrm{C} 4}{ }^{\mathrm{c}}(\%)$} & \multicolumn{2}{|c|}{$\mathrm{NPP}(\mathrm{PgC} / \mathrm{yr})$} \\
\hline & & range & $\bar{x} \pm \mathrm{SD}$ & range & $\bar{x} \pm \mathrm{SD}$ & range & $\bar{x} \pm \mathrm{SD}$ & range & $\bar{x} \pm \mathrm{SD}$ & range & $\bar{x} \pm \mathrm{SD}$ \\
\hline PRE targets & & $\begin{array}{l}622-908 \\
\end{array}$ & & $1150-1700$ & & $1911-2422$ & & 19-21 & & $53-60$ & \\
\hline PRE steady state & 1 & & 669 & & 1504 & & 2174 & & 20 & & 58 \\
\hline LGM targets & & $352-640$ & & $806-1405$ & & $1083-1870$ & & $30-33$ & & $35-41$ & \\
\hline LGM Kheshgi $^{\mathrm{d}}$ & 1 & & $237 / 384$ & & $658 / 871$ & & $895 / 1255$ & & $28 / 20$ & & $16 / 23$ \\
\hline LGM Kicklighter $^{\mathrm{e}}$ & 1 & & 55 & & 554 & & 609 & & 54 & & 12 \\
\hline LGM all results & 9720 & $27-1481$ & $446 \pm 339$ & $310-2668$ & $1110 \pm 506$ & $336-4149$ & $1555 \pm 843$ & $7-80$ & $34 \pm 19$ & $7-95$ & $35 \pm 21$ \\
\hline LGM C $^{f}$ & 2067 & $352-633$ & $458 \pm 66$ & $840-1381$ & $1126 \pm 111$ & $1195-1870$ & $1584 \pm 165$ & $12-45$ & $25 \pm 6$ & $26-51$ & $37 \pm 5$ \\
\hline LGM $f_{\mathrm{C} 4} \mathrm{~g}$ & 543 & $122-649$ & $345 \pm 102$ & $523-1629$ & $986 \pm 225$ & $645-2278$ & $1331 \pm 326$ & $30-33$ & $31 \pm 1$ & $15-51$ & $30 \pm 7$ \\
\hline LGM NPP $^{\mathrm{h}}$ & 997 & $330-613$ & $479 \pm 54$ & $930-1435$ & $1170 \pm 93$ & $1321-1962$ & $1649 \pm 129$ & $13-41$ & $24 \pm 6$ & $35-41$ & $38 \pm 2$ \\
\hline $\mathrm{LGM} \mathrm{C}+f_{\mathrm{C} 4}$ & 214 & $352-531$ & $422 \pm 46$ & $930-1377$ & $1152 \pm 107$ & $1294-1870$ & $1573 \pm 150$ & $30-33$ & $31 \pm 1$ & $27-45$ & $35 \pm 4$ \\
\hline LGM C+NPP & 956 & $354-613$ & $477 \pm 52$ & $930-1381$ & $1162 \pm 86$ & $1321-1870$ & $1639 \pm 121$ & $13-41$ & $24 \pm 6$ & $35-41$ & $38 \pm 2$ \\
\hline LGM $f_{\mathrm{C} 4}+\mathrm{NPP}$ & 105 & $354-551$ & $451 \pm 46$ & $1035-1412$ & $1227 \pm 84$ & 1399-1962 & $1677 \pm 126$ & $30-33$ & $31 \pm 1$ & $35-41$ & $37 \pm 2$ \\
\hline $\mathrm{LGM} \mathrm{C}+f_{\mathrm{C} 4}+\mathrm{NPP}$ & 98 & $354-531$ & $445 \pm 41$ & $1035-1357$ & $1216 \pm 75$ & $1399-1862$ & $1660 \pm 112$ & $30-33$ & $31 \pm 1$ & $35-41$ & $37 \pm 2$ \\
\hline LGM transient case $\mathrm{I}^{\mathrm{i}}$ & 14 & $367-490$ & $428 \pm 45$ & $1098-1360$ & $1203 \pm 82$ & $1468-1850$ & $1632 \pm 123$ & $30-33$ & $32 \pm 1$ & $35-40$ & $37 \pm 2$ \\
\hline LGM transient case $\mathrm{II}^{\mathrm{j}}$ & 12 & $370-486$ & $428 \pm 32$ & $1108-1301$ & $1193 \pm 54$ & $1479-1787$ & $1621 \pm 84$ & $30-33$ & $31 \pm 1$ & $34-39$ & $36 \pm 2$ \\
\hline
\end{tabular}

a vegetation $=\mathrm{C} 4+\mathrm{C} 3+\mathrm{NW}+\mathrm{W}$.

b Soil $=\mathrm{D}+\mathrm{FS}+\mathrm{SS}$.

${ }^{\mathrm{c}}$ Fraction of the total biospheric carbon stock which consists of $\mathrm{C}_{4}$ material.

d After Kheshgi et al. (1996): $\beta=0.42, Q_{10}^{\mathrm{C} 4}=1.4, Q_{10}^{\mathrm{RES}}=2.0 \mathrm{~A}: Q_{10}^{\mathrm{C} 3}=1.53, \mathrm{~B}: Q_{10}^{\mathrm{C} 3}=1.4$.

e After Kicklighter et al. (1999): $\beta=0.287, Q_{10}^{\mathrm{C} 4}=1.0, Q_{10}^{\mathrm{C} 3}=1.0, Q_{10}^{\mathrm{RES}}=1.0$.

${ }^{\mathrm{f}}$ Scenarios which meet the carbon stocks standards.

$\mathrm{g}$ Scenarios which meet the $\mathrm{C}_{3} / \mathrm{C}_{4}$ distribution.

h Scenarios which meet the NPP targets.

${ }^{i}$ Scenarios with moderate $\mathrm{CO}_{2}$ fertilization $(\beta=0.1)$, reasonable forcings and all targets fullfilled.

j Scenarios with low $\mathrm{CO}_{2}$ fertilization $(\beta<0.1)$, reasonable forcings and all targets fullfilled. 


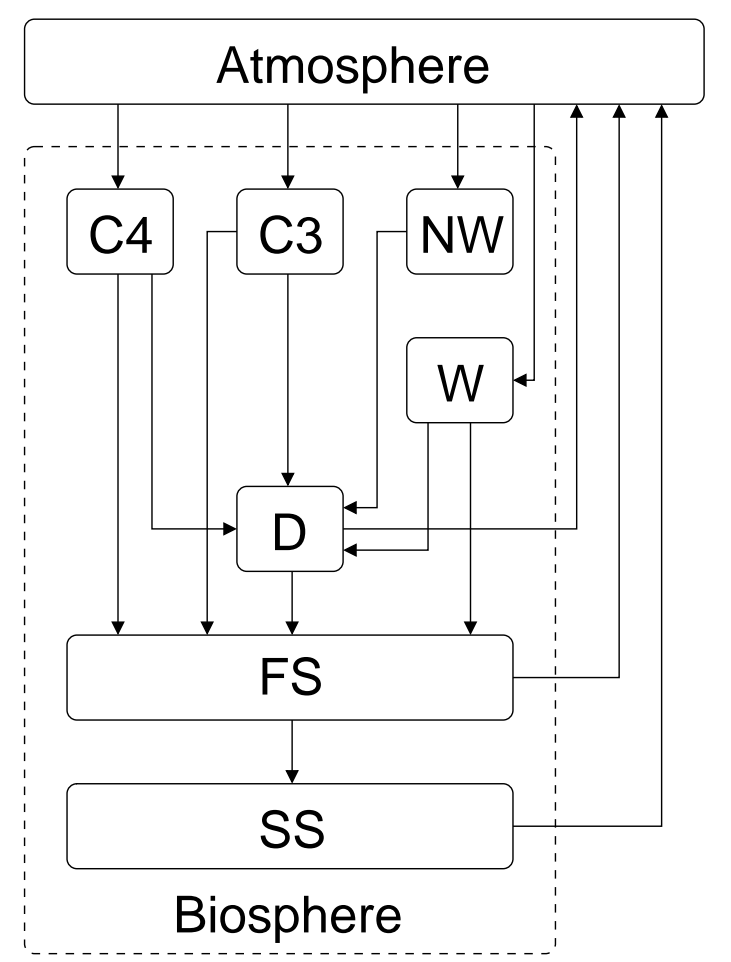

Fig. 1. KÖHLER \& FISCHER 


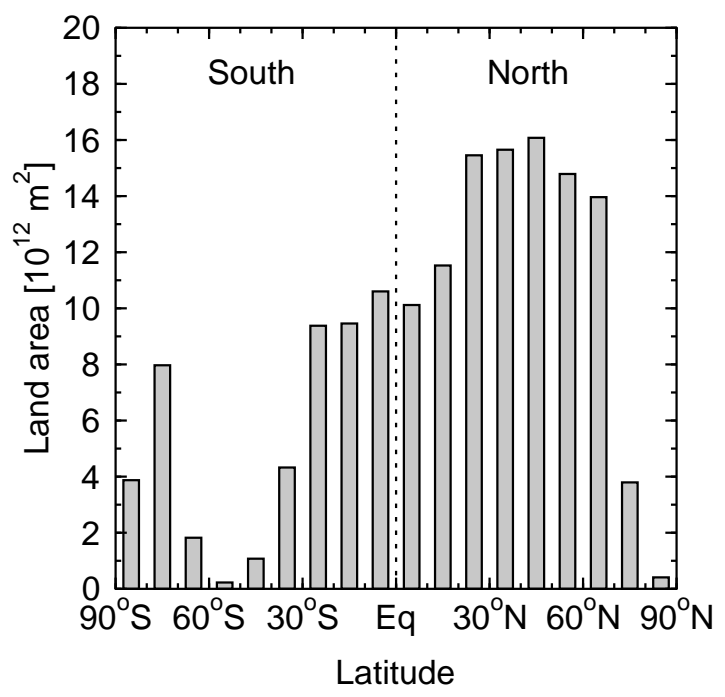

Fig. 2. KÖHLER \& FISCHER 


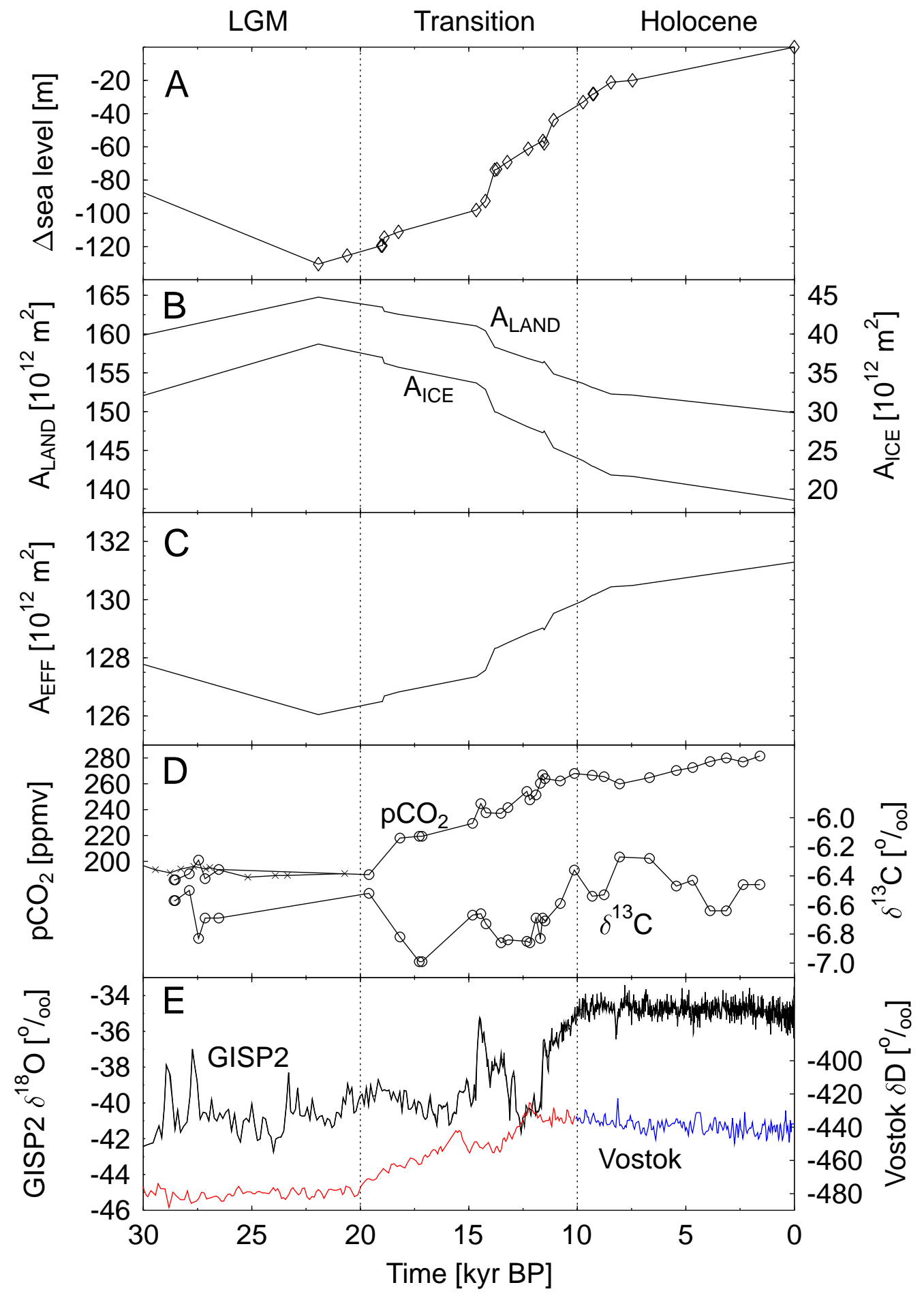

Fig. 3. KÖHLER \& FISCHER 


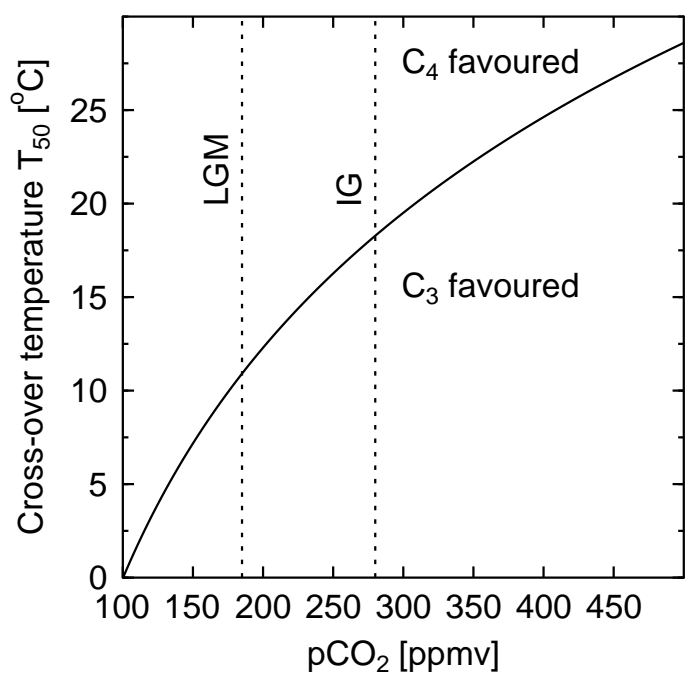

Fig. 4. KÖHLER \& FISCHER 


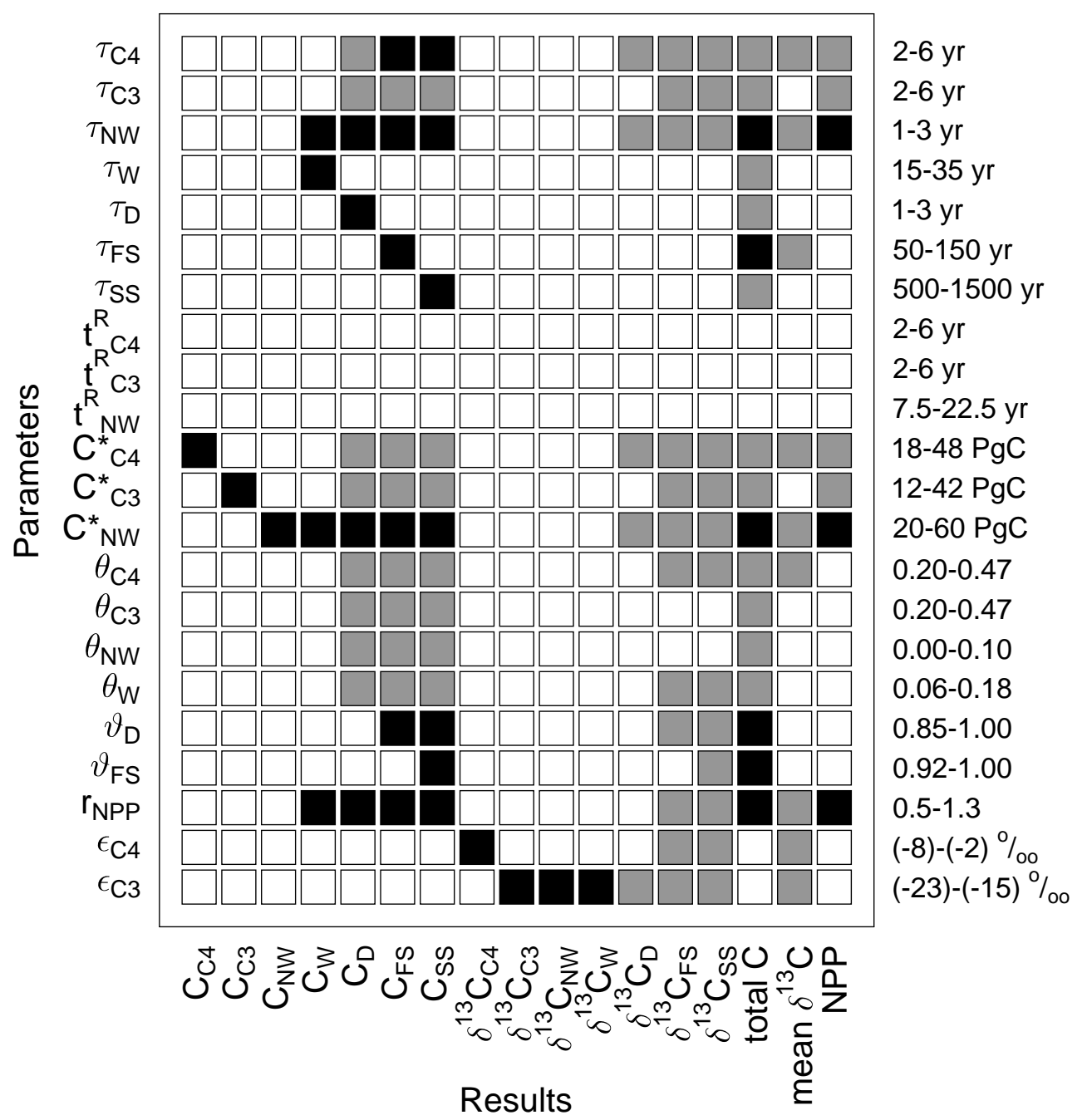

Fig. 5. KÖHLER \& FISCHER 


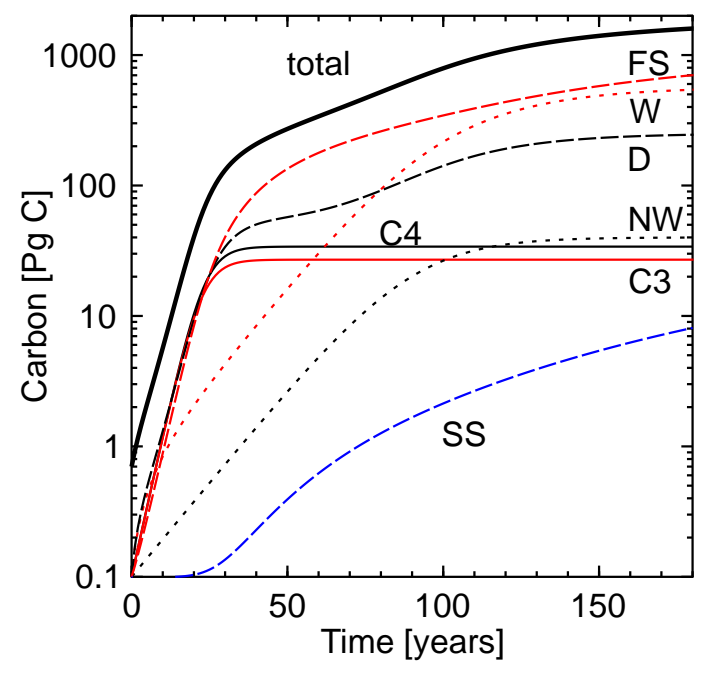

Fig. 6. KÖHLER \& FISCHER 
Impact of $\mathrm{pCO}_{2}$ fertilization

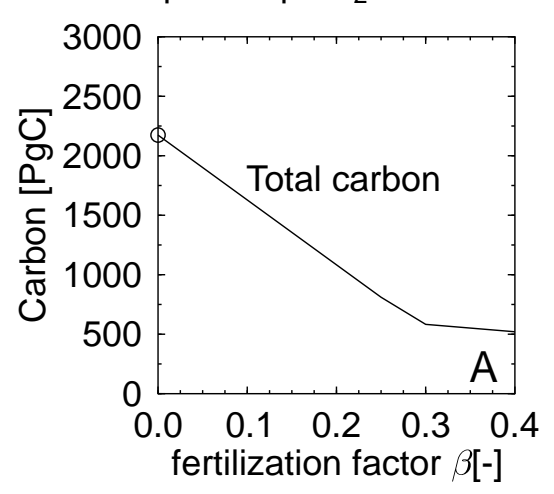

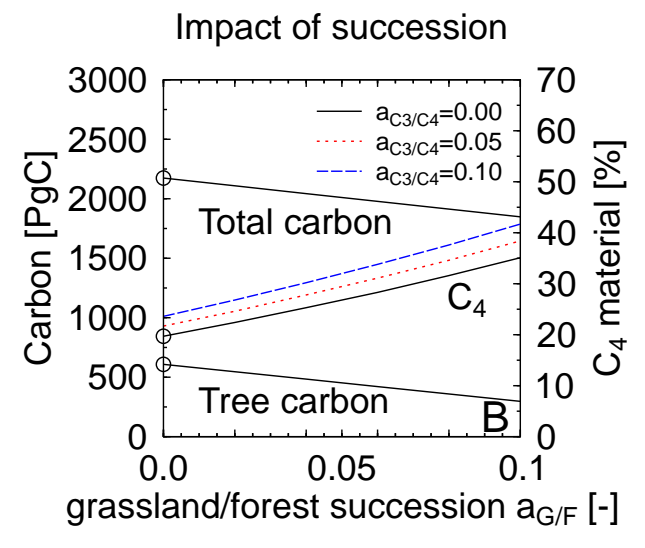

metabolic change of total carbon

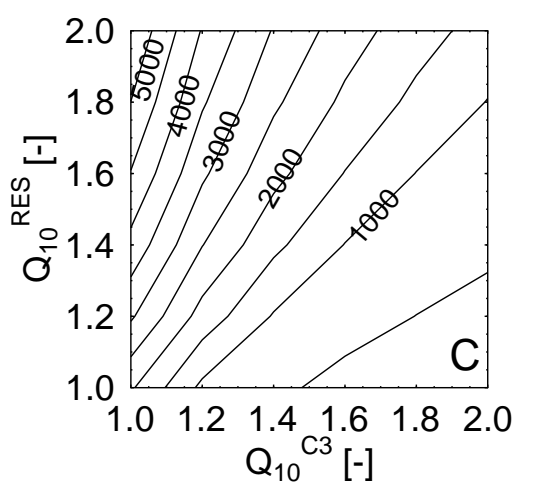

Fig. 7. KÖHLER \& FISCHER 


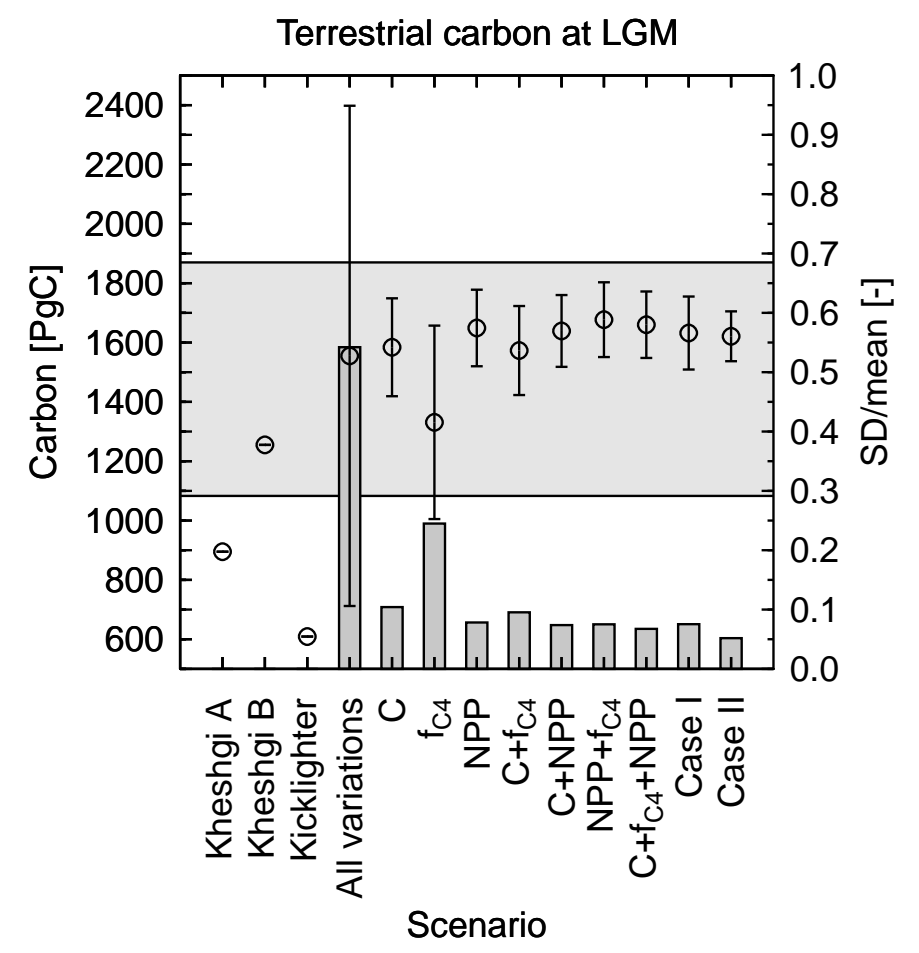

Fig. 8. KÖHLER \& FISCHER 

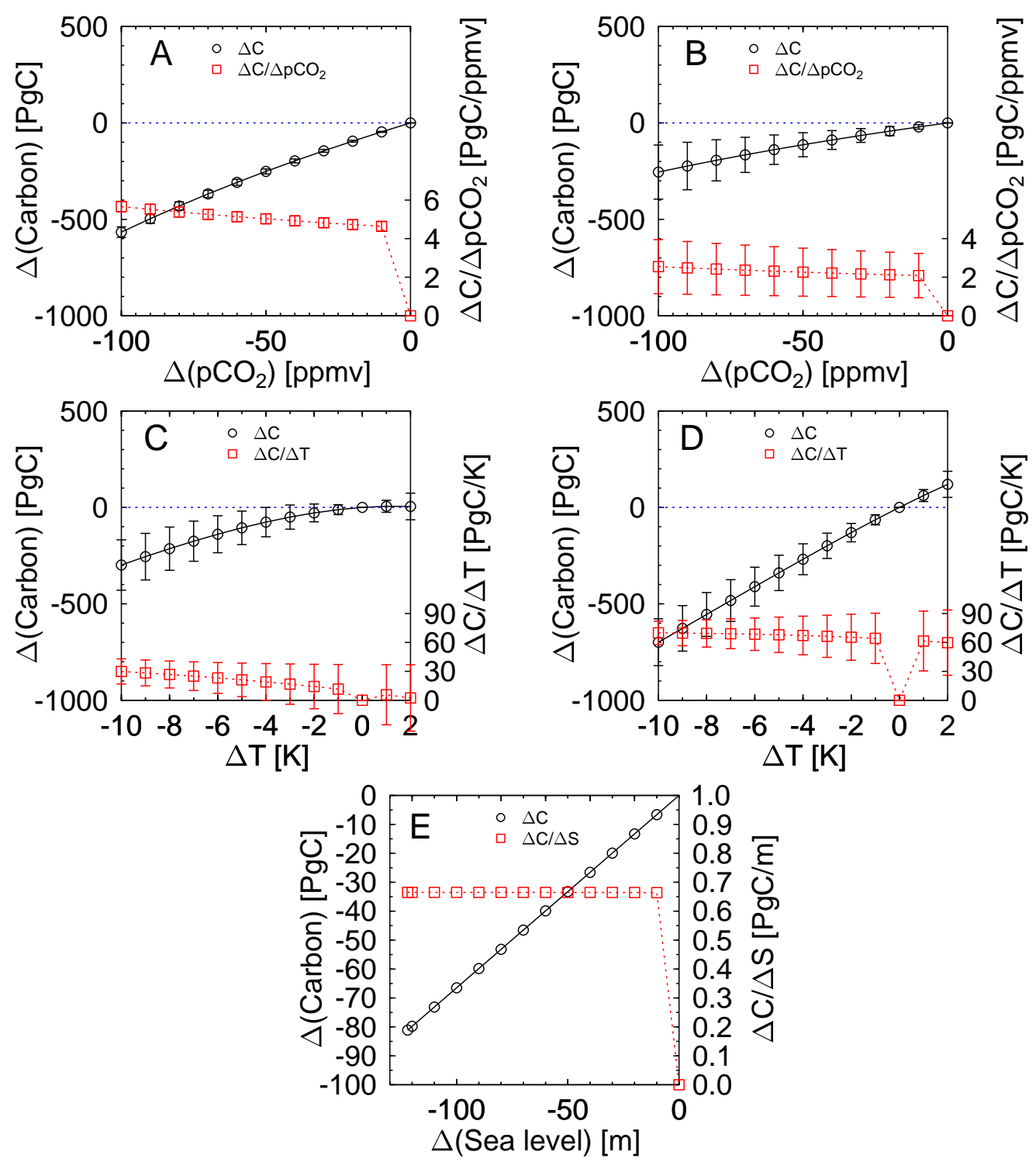

Fig. 9. KÖHLER \& FISCHER 


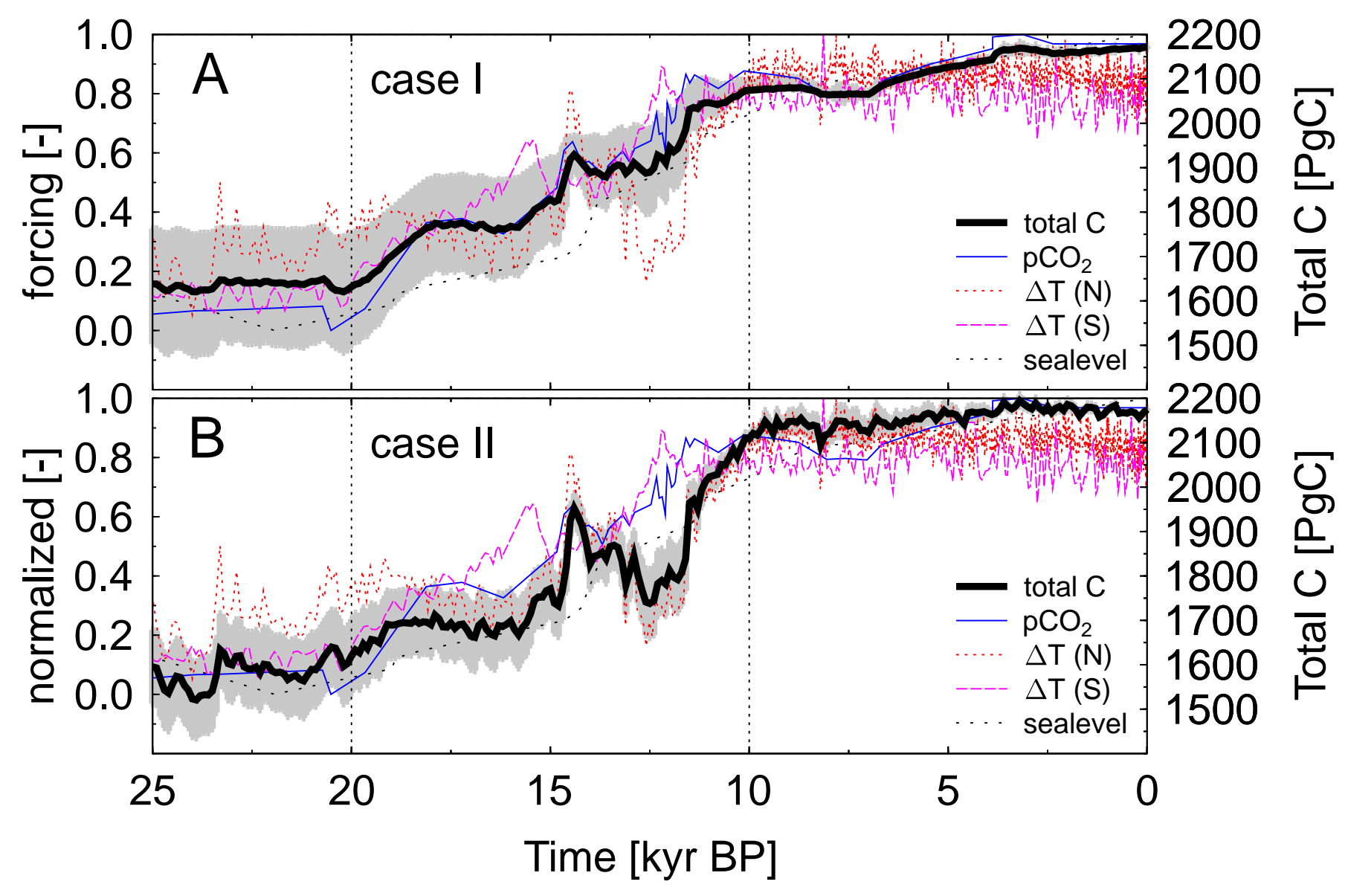

Fig. 10. KÖHLER \& FISCHER 


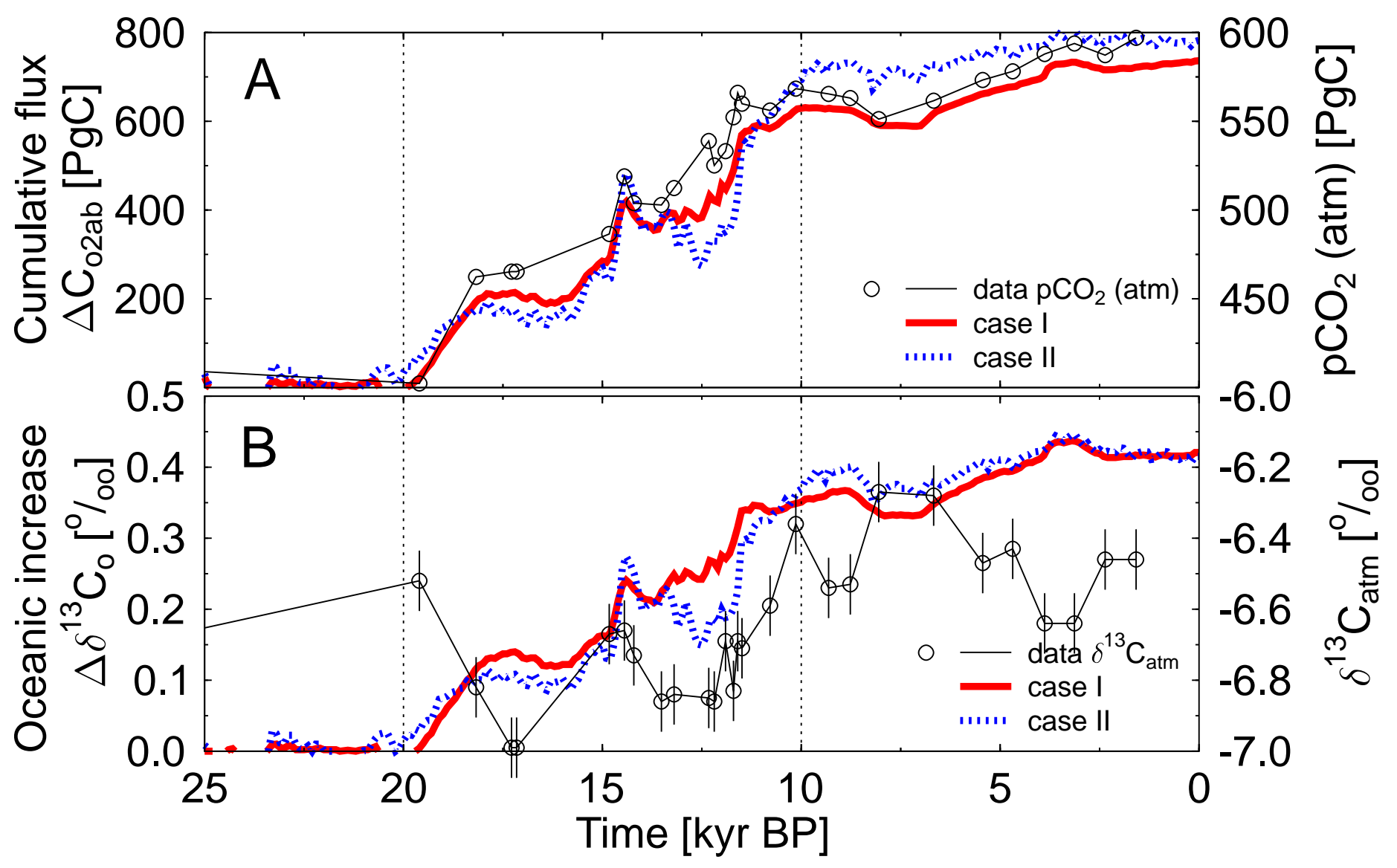

Fig. 11. KÖHLER \& FISCHER 